\title{
Promoting Racial and Ethnic Diversity among Canadian Academic Librarians
}

\author{
Mary Kandiuk
}

This study examines racial and ethnic diversity among Canadian academic librarians and discusses the findings of a nationwide survey. The survey posed questions related to equity plans and programs as well as recruitment practices for academic librarians from equity-seeking groups with a focus on Aboriginal and visible/racial minority librarians. It explored the needs and experiences of Aboriginal and visible/racial minority librarians employed in Canadian academic libraries by examining questions of organizational climate, mentoring, institutional support, advancement opportunities, and the roles of library associations. The findings reveal a need for more diversity awareness and training and leadership with respect to diversity on the part of academic libraries and the profession at large in Canada.

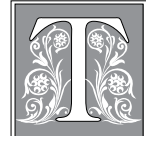

he Canadian population is increasingly racially and ethnically diverse. This demographic change is reflected in all parts of Canadian society including the students enrolled at Canadian universities. Government programs and

legislation have introduced measures to eliminate barriers to employment to ensure that racial and ethnic diversity is represented in the workforce including the academic staff at postsecondary institutions. Canadian academic libraries must strive to ensure that professional staff are reflective of the demographic change that they see in students and in teaching faculty. This paper will discuss the findings of a nationwide survey distributed to approximately 1,500 Canadian academic librarians employed at Canadian universities in June 2011. The study sought to answer the following questions:

- What are the issues and challenges faced by Canadian academic libraries with respect to the recruitment and retention of a racially and ethnically diverse professional workforce?

- What are the strategies and best practices that can be used to recruit a professional workforce that is reflective of our campus communities and society at large?

- How can Canadian academic librarians support their racially and ethnically diverse academic librarian colleagues?

- And how can Canadian academic librarians advocate for and promote racial

Mary Kandiuk is Visual Arts, Design and Theatre Librarian/Senior Librarian, Research and Collections in Scott Library at York University; e-mail: mkandiuk@yorku.ca. (c) 2014 Mary Kandiuk, AttributionNonCommercial (http://creativecommons.org/licenses/by-nc/3.0/) CC BY-NC 
and ethnic diversity in the library profession beyond the confines of their own academic institutions?

With an overall response rate of 36.5 percent, with 1.1 percent of the respondents identifying as Aboriginal and 11 percent as visible/racial minority, the study is an indepth examination of racial and ethnic diversity and academic librarians in Canada. According to Section 3 of the Employment Equity Act, 1995, "'Aboriginal peoples' means persons who are Indians, Inuit or Métis" and "'members of visible minorities' means people, other than Aboriginal peoples, who are non-Caucasian in race or nonwhite in colour."1

What follows is a review of the literature relating to racial and ethnic diversity among academic librarians with a focus on Canada; an examination of data and statistics as they inform this study; a review of employment equity and Canadian universities; a description of the survey goals and methodology; a detailed discussion of the survey results followed by a summary and limitations of the survey; concluding with recommendations and avenues for further research.

\section{Literature Review}

As is illustrated by The Kaleidoscope Concern: An Annotated Chronological Bibliography of Diversity, Recruitment, Retention, and Other Concerns Regarding African American and Ethnic Library Professionals in the United States, compiled by Kaetrena D. Davis-Kendrick and published by the Association of College and Research Libraries in 2009, the literature relating to ethnic and racial diversity and librarians in the United States is extensive, dating as far back as the 1920s. ${ }^{2}$ Composed of over 300 entries, the largest number of these entries fall under the category of "Recruitment and Retention," divided into two sections - "Library Education" and "Workplace/Career" - revealing an ongoing concern with the recruitment of racial and ethnic minorities into LIS education as well as the representation of racial and ethnic minority librarians in libraries.

As discussed by Kyung-Sun Kim and Sei-Ching Joanna Sin in "Increasing Ethnic Diversity in LIS: Strategies Suggested by Librarians of Color," published in The Library Quarterly in 2008, studies relating to recruitment and retention into LIS programs have examined factors affecting the decision to enter the LIS profession, barriers to the recruitment of minorities into LIS, and strategies for effective recruitment and retention. ${ }^{3}$ Their study "aimed at assessing what LIS schools and other library and information professional associations have done for the recruitment and retention of students of color and identifying effective strategies for the recruitment and retention from the perspective of librarians of color." ${ }^{4}$ The study highlights the ongoing underrepresentation of ethnic minorities in LIS schools. Strategies for recruitment fall into three categories: financial support and work/career opportunity, diversity in faculty/ staff and students/alumni, and active recruitment including advertisement and personal contacts. ${ }^{5}$ Strategies for retention also fall into three categories: financial support and work/career opportunity; support by faculty/staff, students, and ethnic associations; and curriculum and class schedule. ${ }^{6}$ The findings also reveal significant differences among ethnic minority groups, and that among Native Americans "offering distance learning options in LIS programs was ranked consistently higher than in other groups," for both recruitment and retention. ${ }^{7}$ The Kaleidoscope Concern reveals that studies relating to workplace/career recruitment and retention of African American and ethnic library professionals have explored the areas of internships and residencies, fellowships and scholarships, leadership and career development, professional development, mentoring, and support for research. In a recent study, "Tenure and Promotion Experiences of Academic Librarians of Color," published in College $\mathcal{E}$ Research Libraries in 2012, Ione T. Domasco and Dracine Hodges examine "factors impacting work-life experiences of 
library faculty of color within the framework of tenure policies and processes." ${ }^{8}$ The study reveals the challenges faced by library faculty of color as they "work toward their professional goals," including workload issues and "implicit and explicit racism." ${ }^{\prime 9}$ Recommendations to ensure more positive experiences for library faculty of color include: ensuring equitable tenure-track experiences for librarians of color and periodic assessments of policies and processes; assessment of mentoring or peer support groups; and acknowledging the "value of work of library faculty of color who engage with and provide service to communities of color served by their institutions." 10

What is also revealed in a review of the literature is leadership on the part of bodies such as the American Library Association (ALA), the Association of College and Research Libraries (ACRL), and the Association of Research Libraries (ARL) in the area of diversity at both the association and institutional level in the United States. This has included both the development and ongoing review of diversity initiatives and programs. A recent major initiative is the development of the ACRL Diversity Standards: Cultural Competency for Academic Libraries (2012), which "are intended to emphasize the need and obligation to serve and advocate for racial and ethnically diverse constituencies."11 This was preceded by Achieving Racial and Ethnic Diversity among Academic and Research Librarians: The Recruitment, Retention, and Advancement of Librarians of Color, a White Paper by the ACRL Board of Directors Diversity Task Force issued in 2007. The White Paper provides recommended goals in each of the areas of recruitment, retention, and advancement "of groups traditionally underrepresented in the academic library workforce." The objectives of the White Paper are also to "discuss efforts to promote, develop, and foster workforces that are representative of a diverse population and address the development of a climate that supports and encourages advancement." 12

While there is a large body of literature relating to racial and ethnic diversity and academic librarians in the United States, the same does not hold true for Canada. In 2010, the Association of Research Libraries (ARL) published SPEC Kit 319 Diversity Plans and Programs. It presents the results of a survey that explored the progress that has been made in ARL member libraries to "recruit and retain a diverse workforce and to identify the existence and content of diversity plan documents; the strategies they use to increase the number of ethnically/culturally diverse librarians to the profession and in their libraries; the elements of programs that successfully support an inclusive workplace; the people, groups, and/or committees responsible for overseeing the programs; and how libraries are assessing the effectiveness and success of such programs."13 A total of 49 ARL member institutions completed the survey; 9 of those responses were from Canadian institutions. However, no breakdown is provided by institution, and responses from Canadian institutions are not differentiated from those of U.S. institutions. In addition, among the documents included, not a single document is provided from a Canadian institution.

In 2005, the University of Alberta undertook a comprehensive study of the human resources challenges facing Canadian libraries. According to The Future of Human Resources in Canadian Libraries (8Rs Report), "visible minorities are not well represented in Canadian libraries, comprising only $7 \%$ of the professional librarian labour force (compared to $14 \%$ in Canada's entire labour force). The largest proportion of visible minorities is found in non-profit and for-profit special libraries (11\% and $10 \%$, respectively), although this is still below the national average. Visible minorities are even less likely to be working as senior administrators, and this is the case for all but the government sector." Meanwhile, "Aboriginal librarians are not well represented in the Canadian labour force (comprising 3\% of the total labour force), but they are even less visible in the library community in all sectors and at all occupational levels." ${ }^{14}$ 
A study of indigenous knowledge in an academic library from an indigenous perspective, published by Deborah Lee from the University of Saskatchewan in 2008, identifies a "lack of Aboriginal librarians and the responsibilities involved in the stewardship of Indigenous Knowledge in an academic library setting, such as including a cultural component in the teaching of information literacy skills and engaging in collection development activities." One of the main findings is that students "were hoping to see more Aboriginal role models on campus as professors or librarians." ${ }^{15}$ Creating a Representative Library Workforce in Saskatchewan, published by the Multitype Library Board in 2008, provides an environmental scan of Aboriginal labour force and education trends in that province; discusses the barriers/issues related to creating a diverse workforce in Saskatchewan libraries; and describes the experiences and strategies to promote and develop a representative workforce. Barriers identified include: lack of information and awareness about careers in libraries; lack of career planning and finding available training; no Master of Library Science program in Saskatchewan; workplace issues including unwelcoming staff; and lack of supports including social supports, mentors, transportation, and childcare. One of the strategies proposed to increase the number of Aboriginal librarians is online library science education, which is seen as a "more viable option" to accommodate the needs of Aboriginal people who are reluctant to "leave their families and communities for out-of-province education." 16

The most recent work, Leadership in Libraries: A Focus on Ethnic-Minority Librarians, published in 2012 by Maha Kumaran from the University of Saskatchewan, discusses ethnic-minority leadership in libraries including "[1]eadership in school, public and academic libraries in the US, the UK, Canada and Australia." It provides an "overview of leadership theories and connects them to the needs of immigrant librarians." ${ }^{17} \mathrm{On}$ the basis of the results of surveys that were sent to ethnic-minority librarians, deans and directors of libraries, and directors of library schools, Kumaran stresses the unique needs of first-generation immigrant librarians (as compared to second and third generation) who face additional cultural challenges.

A review of the literature identifies a need for research in the area of racial and ethnic diversity and academic librarians in Canada. The findings from this study will contribute to original research in this area and will lay the foundation for future research. The results may also be used to develop, inform, and strengthen diversity initiatives and programs at the institutional and library association level in Canada.

\section{Data and Statistics}

According to the 2006 Canadian Census, Aboriginal people in Canada-First Nations, Métis, and Inuit-surpassed the one-million mark, reaching $1,172,790 .{ }^{18}$ Some provinces, such as Saskatchewan and Manitoba, reported an Aboriginal population of 15 percent in 2006. ${ }^{19}$ Meanwhile "visible minorities" accounted for 16.2 percent of the total population in Canada in 2006. ${ }^{20}$ Immigration is a key factor accounting for the increase in the visible minority population. Three-quarters $(75 \%)$ of the immigrants who arrived between 2001 and 2006 belonged to a visible minority group; between 2001 and 2006, "Canada's visible minority population increased by $27.2 \%$ which is five times faster than the $5.4 \%$ growth rate of total population." ${ }^{21}$ The numbers for individuals who identify as visible minority varies greatly depending on geographical location. In 2006, visible minorities represented 22.8 percent ( 2.7 million) of Ontario's total population and more than half of Canada's total visible minorities (5.1 million). Most of Canada's visible minority population (95.9\%) live in or around "urban centres." “[A]lmost threequarters of Canada's visible minority population lived in the census metropolitan area of Toronto (2.2 million), Vancouver $(875,000)$ or Montreal $(590,000)$. In addition to this, 
the census metropolitan areas of Calgary, Ottawa-Gatineau, Edmonton and Winnipeg were each home to at least 100,000 visible minorities." 22

In 2006, the visible minority status of Canadian university teachers was 14.9 percent. Canadian university teachers that identified as Aboriginal was 1 percent. ${ }^{23}$ According to data from the National Survey on Student Engagement (NSSE) for 2006, 33 percent of first-year students in the province of Ontario were visible minority, with some institutions such as York University in Toronto reporting as high as 40 percent of first-year students identifying as visible minority. ${ }^{24}$ However, current and comprehensive demographic data for librarians employed at or graduating from library/information science programs in Canada is difficult to locate or in some cases simply not available. Census data available via the "National Occupational Classification for Statistics" provides librarian numbers broken down by gender and by visible minority status. The data reveals that, in 2006, the total librarian labour force was 11,975, with 2,085 identifying as male and 9,890 identifying as female. Meanwhile, the 2006 librarian labour force by visible minority groups was 1,160, with 260 identifying as male and 905 identifying as female. ${ }^{25}$ This means that, out of the total pool of librarians, approximately 9.7 percent of librarians identified as visible minority. This is less than the visible minority population represented in Canada's entire labour force, which in 2006 was 17,146,135, with 15.4 percent $(2,639,520)$ identifying as visible minority. The largest race/ethnic identity represented among visible minority librarians, as is illustrated in table 1, was Chinese. Aboriginal data are not captured in this data set and are only available for a fee from Statistics Canada. ${ }^{26}$ According to Lee, "[a]s of 2004, there were fewer than 25 Aboriginal librarians (with master's degrees in library and information studies) in Canada (8Rs Research Team: University of Alberta, which provided me with raw data they had collected). ${ }^{27}$ Meanwhile, the total labour force that identified as Aboriginal in 2006 was 517,375-approximately 3 percent. ${ }^{28}$

Mirroring the geographical distribution of the visible minority population in Canada, the greatest concentration of visible minority librarians was found in or around urban centres, with Toronto reporting the highest number of visible minority librarians (approximately $37 \%$ of the national pool; $n=425$ ), followed by Vancouver (approximately $17 \% ; n=195)$, and Montreal (approximately $10 \% ; n=120$ ). Several provinces (Newfoundland and Labrador, Prince Edward Island, Northwest Territories) reported no visible minority librarians, as did many Canadian cities where universities are located (such as Moncton, Saint John, Fredericton, Peterborough, St. Catharines, Sudbury, Thunder Bay, Brandon, Saskatoon, Lethbridge). However, a breakdown is not available by librarian sector (in other words, academic, public, special). The Canadian Association of Research Libraries (CARL) and the Canadian Association of University Teachers (CAUT) provide only numbers, ranks, and salary data for academic librarians for member institutions. ARL provides "ethnicity/

\begin{tabular}{|l|c|c|}
\hline \multicolumn{3}{|c|}{ TABLE 1 } \\
Librarians by Visible Minority \\
Groups According to 2006 Canadian \\
Census (N = 1160)
\end{tabular}


race of professional staff" for U.S. ARL university libraries only. Meanwhile, schools of library and/or information science in Canada are not legally allowed to collect or disseminate data relating to students from equity seeking groups. ${ }^{29}$

\section{Employment Equity and Canadian Universities}

The Federal Contractors Program was established in 1986 to "further the goal of achieving workplace equity for designated groups experiencing discrimination in the Canadian labour market." These groups are: women; Aboriginal peoples; persons with disabilities; and members of visible minorities. Under the program, universities are required to implement employment equity and are subject to compliance reviews. ${ }^{30}$ These compliance reviews, made available by some institutions on their websites, provide data with respect to numbers of employees within the designated groups comparing these numbers against market availability for those groups. It is difficult to determine how well an institution is fulfilling its obligation with respect to professional librarians because they are included under the Occupational Group "Professional," which includes a range of occupations (unlike "Professors," who are clearly identified). Selected universities have made this information available. In 2011, Queen's University reported 0.0 percent of librarians as Aboriginal (as compared to $0.8 \%$ of full-time professors) and 4.7 percent librarians as Visible Minorities (as compared to $10.6 \%$ of full-time professors). ${ }^{31}$ Meanwhile, in 2011, the University of Toronto reported 0.0 percent of librarians as Aboriginal (as compared to $0.4 \%$ of faculty) and 12 percent of librarians as Visible Minorities (as compared to $15 \%$ of faculty). ${ }^{32}$ Universities have developed equity plans to assist them in fulfilling their obligations under the Federal Contractors Program to advance equity and diversity at their institutions. These plans will vary by institution but usually include general underlying principles. Employment equity plans that relate to academic staff may be broad-based at the institutional level, such as the University of Lethbridge's Best Practices for Hiring with a Focus on Diversity $\mathcal{E}$ Equity to Support Departments in the Search and Selection of New Faculty and Professional Librarians, ${ }^{33}$ or they may be unit-based, such as York University Libraries' Affirmative Action Plan, ${ }^{34}$ or a combination, such as at Memorial University. ${ }^{35}$

Academic staff associations have also played an important role in advancing employment equity at universities. The Canadian Association of University Teachers (CAUT) Policy Statement on Equity issues the following directive to member institutions: "Academic staff associations should take a leadership role in the realization of equity by negotiating equity provisions in agreements and by promoting equity within the association and its governance structure." ${ }^{36}$ Many of the collective agreements covering academic staff at Canadian universities contain clauses addressing employment equity that are intended to ensure that diversity is reflected in the academic staff at those institutions (one example is Article 24: Employment Equity, Collective Agreement, Queen's University Faculty Association). ${ }^{37}$

\section{Survey Goals and Methodology}

The first goal of the survey was to ascertain the progress that has been made by Canadian academic librarians with regard to fostering racial and ethnic diversity within their ranks. It set out to explore how knowledgeable they are about employment equity and also their support for racial and ethnic diversity. The survey collected information regarding recruitment and retention practices for academic librarians from equity-seeking groups (as defined by the Federal Contractors Program) at Canadian universities, with a focus on Aboriginal and visible/racial minority librarians. It posed questions relating to equity plans and programs as well as outreach in hiring for academic librarians from underrepresented groups. The second goal of the survey was to 
explore the needs and experiences of Aboriginal and visible/racial minority academic librarians employed in Canadian academic libraries by examining questions of organizational climate, mentoring, institutional support, advancement opportunities, and the roles of library associations.

A web-based survey was developed using both closed- and open-ended questions. The survey was divided into two parts. The first part was composed of 32 questions and was open to all academic librarians. The second part was composed of 27 questions and was open only to Aboriginal and visible/racial minority librarians (with identical questions for each group). The survey was pretested using a small group $(n=3)$ of academic librarians, including one librarian who identified as visible/racial minority and two who did not. Efforts were made to distribute the survey to every academic librarian employed at a Canadian university. This involved compiling a database of academic librarian e-mail addresses using university and academic library staff directories accessed on individual university websites across Canada. Each librarian was sent an individual survey link by the author via e-mail. The survey was distributed to 1,520 academic librarians on May 30,2011. A second direct mailing was distributed to 1,489 librarians on June 21, 2011, with a final reminder on June 28, 2011. To capture those librarians who may have been inadvertently missed, a request for assistance with distribution of the survey was made to the following: 62 Canadian academic library directors (June 5, 2011); 47 Canadian faculty associations who are members of the CAUT (June 12, 2011); and the CAUT Librarians' Discussion Electronic Mail List (June 15, 2011). The survey remained open for one month and closed on June 30, 2011. A total of 543 responses was received representing a 36.5 percent response rate. Only 1.1 percent $(n=6)$ of respondents identified as Aboriginal; 11 percent $(n=60)$ of respondents identified as visible/racial minority.

\section{Survey Results and Discussion}

\section{Part 1-General Questions}

A total of 543 librarians responded to the survey. The majority of the respondents $(51.9 \% ; n=282)$ were from institutions with more than 24,000 full-time students. The second largest group of respondents $(24.7 \% ; \mathrm{n}=134)$ were from small institutions with less than 12,000 full-time students, and the remaining respondents $(23.4 \% ; n=127)$ were from mid-size institutions with between 12,000 and 24,000 full-time students. The majority of the respondents $(57.0 \% ; \mathrm{n}=308)$ were from institutions located in cities or towns with a population greater than 500,000 . The second largest group $(24.3 \%$; $\mathrm{n}=131$ ), were from institutions located in cities or towns with a population between 150,000 and 500,000 , and the remaining respondents $(18.7 \% ; n=101)$ were located in cities or towns with a population less than 150,000.

The most frequently occurring response on the part of respondents indicated that they had been employed by their institutions for less than 5 years $(38.6 \%$; $n=208)$. However, the most frequently occurring response on the part of respondents also indicated more than 20 years of professional experience in total $(33.5 \% ; n=180)$.

Reflecting the gender distribution within the profession, the majority of the respondents were female $(76.9 \% ; \mathrm{n}=410)$. Respondents worked in a number of different areas within their libraries with the majority $(68.3 \% ; n=355)$ reporting responsibility for Reference/Instructional Services followed by Collection Development/Collection Management $(43.8 \% ; n=228)$.

\section{Employment Equity Plans}

The survey revealed a high level of unfamiliarity with employment equity plans on the part of Canadian academic librarians. When asked whether their library had 
“an Employment Equity / Affirmative Action Plan that outlines proactive measures or strategies for recruiting qualified librarians who are women, Aboriginal peoples, persons with disabilities and members of visible minorities," the greatest number of respondents indicated that they did not know $(44.6 \% ; n=227)$, followed by yes $(41.1 \%$; $\mathrm{n}=209)$. Of those who indicated that their institution had such a plan, 84.1 percent ( $\mathrm{n}$ $=195$ ) indicated that this was part of a broader institutional plan. Only 3.9 percent (n $=9$ ) indicated that this was a separate library plan. Almost 6 in 10 respondents $(59.9 \%$; $\mathrm{n}=139$ ) reported being somewhat familiar with this plan, followed by 22.4 percent $(\mathrm{n}=52)$ "not at all familiar," and 17.7 percent $(\mathrm{n}=41)$ "very familiar." Neither size of institution nor years of professional experience made any discernible difference in responses. In most cases $(53.7 \% ; n=117)$, the plan was posted on the library/institutional website, followed by "distributed to all hiring committees" $(41.3 \% ; n=90)$, and then "distributed to all new hires" $(25.7 \% ; n=56)$, followed closely by "don't know where it is made available" $(25.2 \% ; n=55)$. Further supporting the notion that there was general unfamiliarity with employment equity plans on the part of respondents, a number $(n=6)$ indicated in the "Other" category that the plan is "included in the job posting," clearly confusing employment equity plans with equity statements that are mandated in job postings at Canadian universities. However, one respondent indicated that their "library did an extensive review as part of the Federal Contractor's program; and Equity practices are continually reviewed in the university and applied to librarians (who are members of a collective bargaining unit as well)." When asked how often the library followed its plan, 47.3 percent $(n=106)$ responded "always," followed by 38.3 percent $(n=87)$ "don't know," and then 10.3 percent $(n=23)$ "sometimes." One respondent indicated that it was followed "only with unionized positions, not for administrative positions," which may be the case at institutions (such as York University) where affirmative action falls under the Collective Agreement for faculty and librarians. Another indicated that the "plan is nominally followed but manipulated by search committees."

Of the 213 respondents who responded to the question regarding whether any of the following was included in the plan, the most frequently cited was statement of diversity/equity values or goals for the library $(43.2 \% ; n=92)$, which again suggests that respondents were referring to the equity statement mandated in job postings. This was followed by outline of library programs that promote diversity or ethnic/ cultural sensitivity in the workplace $(14.2 \% ; n=30)$, and strategies for retention and support of librarians from equity seeking groups after they are hired $(9.4 \% ; n=20)$. Many respondents indicated that they did not know if any of the previously mentioned was included in the plan.

\section{Equity Programs and Training}

When asked if there was "anyone responsible for overseeing programs or training relating to diversity/equity in the library," the most frequently occurring response on the part of respondents was that they did not know $(36.3 \%$; $=179)$, followed by "does not have anyone responsible" $(27.8 \% ; n=137)$, and then Human Resources/Personnel/ Executive Officer $(21.5 \% ; \mathrm{n}=106)$. Very few reported a Diversity/Equity/Affirmative Action Office(r) $(8.3 \% ; n=41)$ or Diversity/Equity/Affirmative Action Committee $(5.5 \%$; $\mathrm{n}=27$ ). For those who indicated oversight for diversity at the institutional level, the comments revealed a proactive role on the part of some universities such as "Diversity Ambassadors, trained in workshops with the Diversity \& Equity Office," and "equity assessors on hiring and promotion and tenure committees."

The most frequent response on the part of respondents was that their library did not offer any diversity/equity programs or training for librarians $(44.4 \%$; $=210)$, 
with the next largest number of respondents indicating that they don't know $(26.2 \%$; $\mathrm{n}=124$ ). However, in the "Other" responses category, a number of respondents ( $\mathrm{n}=$ 35) indicated that training was provided at the institutional level, usually by Human Resources. The most common type of training provided were Workshops and Presentations, with one respondent reporting a "mandated university workshop." Unique programs reported by respondents included an "Aboriginal Cultural Training program over the course of a year" and a "new diversity caucus" for interested librarians. A total of 9.5 percent of respondents $(n=45)$ indicated that diversity training was provided for hiring committees.

Only 2.6 percent $(n=13)$ of respondents indicated that their library had conducted a diversity climate assessment to determine staff attitudes toward diversity. One respondent indicated that his or her institution was intending to participate in the ClimateQUAL: Organizational Climate and Diversity Assessment. To date, three Canadian institutions have enrolled in the survey. ${ }^{38}$

\section{Recruitment and Retention of Aboriginal Librarians}

As is illustrated in table 2, 37.5 percent $(n=177)$ of respondents indicated that their institution does not take any steps to reach out and encourage applications from Aboriginal librarians, while 49.4 percent $(n=233)$ reported that they did not know. The most common steps taken were "liaises with library schools," followed closely by "advertises on listserv/discussion lists that target these librarians," and "liaises with library associations." A total of 15 respondents indicated in the "Other" category that an institutional equity statement was included in all job postings. Several respondents also indicated that their institution was actively seeking to hire an Aboriginal librarian.

When asked whether their institution had difficulty recruiting Aboriginal librarians, 80.6 percent $(n=374)$ of respondents indicated that they did not know, followed by 15.3 percent $(n=71)$ who said yes. There were 48 comments in the "Other" category. The most frequent comment $(n=18)$ was along the following lines: "We have never actively recruited [A]boriginal librarians, so we could not claim to have had difficulty." As is illustrated in table 3, the biggest obstacle faced with respect to the recruitment of Aboriginal librarians identified by those respondents who answered this question was a limited pool of qualified applicants $(71.3 \% ; n=67)$, followed by applicants choose not

\begin{tabular}{|l|c|c|}
\hline \multicolumn{3}{|c|}{$\begin{array}{c}\text { TABLE 2 } \\
\text { Steps Library Takes to Encourage Applications from Aboriginal Librarians }\end{array}$} \\
\hline Steps Taken to Encourage Applications & $n$ & $\begin{array}{c}\text { Percentage of } \\
\text { Total Responses }\end{array}$ \\
\hline Advertises in publications/on websites that target these librarians & 37 & $7.8 \%$ \\
\hline Advertises on listservs/discussion lists that target these librarians & 30 & $6.4 \%$ \\
\hline Provides post-MLS internships/residencies / fellowships & 12 & $2.5 \%$ \\
\hline Liaises with library associations & 35 & $7.4 \%$ \\
\hline Liaises with library schools & 39 & $8.3 \%$ \\
\hline Provides financial support including scholarships & 3 & $0.6 \%$ \\
\hline Does not take any steps & 177 & $37.5 \%$ \\
\hline Don't know & 233 & $49.4 \%$ \\
\hline Other & 32 & $6.8 \%$ \\
\hline
\end{tabular}




\begin{tabular}{|l|c|c|}
\hline \multicolumn{3}{|c|}{ TABLE 3 } \\
Obstacles to the Recruitment of Aboriginal Librarians \\
(N = 94)
\end{tabular}

to self-identify/difficult to obtain information from applicants regarding racial/ethnic identity $(40.4 \% ; n=38)$. Several respondents $(n=4)$ indicated that bilingual requirements at their institution posed an obstacle to the recruitment of Aboriginal librarians.

Close to half of the respondents felt that their institutions should be doing more to reach out and encourage applications from Aboriginal librarians $(46.3 \%$; $n=215)$, followed by "don't know" (33.4\%; $n=155)$, and then "no" $(20.3 \% ; n=94)$. In the comments section, a number of respondents $(\mathrm{n}=8)$ indicated that "qualifications and experience should take precedence over race or ethnicity." However, several respondents also provided suggestions as to how to increase the availability of Aboriginal librarians, such as "action needs to take place to encourage people to select librarianship as a career - to grow the Aboriginal librarian pool," and "perhaps the question should be, are library schools recruiting minorities, so that there are qualified minorities available to hire in libraries."

Given the limited number of Aboriginal librarians employed in academic libraries, when asked whether their library had difficulty retaining Aboriginal librarians after they have been hired, the majority of the respondents answered "not applicable" (58.3\%; $\mathrm{n}=280)$, followed by “don't know" (35.8\%; $\mathrm{n}=172)$. Yet when asked whether they considered their library a hospitable and welcoming place for Aboriginal librarians 55.8 percent $(n=263)$ replied yes, followed by $31.8 \%(n=150)$ who answered no. The comments under "Other" may provide some clues as to why respondents may have replied yes, with several indicating that their "library is welcoming to all new librarians and other staff regardless." Yet several respondents also indicated that "we have bullying and racial issues in our library" and "it's not necessarily a welcoming place for any new librarians." A common theme that appeared throughout this portion of the survey was that hiring freezes in place at many institutions posed an obstacle to any kind of recruitment, including that of Aboriginal librarians.

\section{Recruitment and Retention of Visible Minority Librarians}

As is illustrated in table 4, 44.3 percent $(n=202)$ of respondents indicated that they did not know what steps their library took to reach out and encourage applications from visible minority librarians, followed by 39 percent $(n=178)$ who said that their institution does not take any steps. The most common steps taken were "liaises with library schools," followed closely by "liaises with library associations" and "advertises 
TABLE 4

Steps Library Takes to Encourage Applications from Visible Minority Librarians $(\mathrm{N}=\mathbf{4 5 6})$

\begin{tabular}{|l|c|c|}
\hline Steps Taken to Encourage Applications & n & $\begin{array}{c}\text { Percentage of } \\
\text { Total Responses }\end{array}$ \\
\hline $\begin{array}{l}\text { Advertises in publications/on websites that target these } \\
\text { librarians }\end{array}$ & 47 & $10.3 \%$ \\
\hline $\begin{array}{l}\text { Advertises on listservs/discussion lists that target these } \\
\text { librarians }\end{array}$ & 41 & $9 \%$ \\
\hline Provides post-MLS internships/residencies/fellowships & 14 & $3.1 \%$ \\
\hline Liaises with library associations & 52 & $11.4 \%$ \\
\hline Liaises with library schools & 53 & $11.6 \%$ \\
\hline Provides financial support including scholarships & 5 & $1.1 \%$ \\
\hline Does not take any steps & 178 & $39 \%$ \\
\hline Don't know & 202 & $44.3 \%$ \\
\hline Other & 41 & $9.0 \%$ \\
\hline
\end{tabular}

in publications/on websites that target these librarians." As with Aboriginal librarians, very few offered post-MLS internships/residencies/fellowships or financial support including scholarships. Again, in the "Other" category, a number of respondents (n $=20$ ) indicated that their institution included an equity statement in the job posting.

Meanwhile, 54.2 percent of respondents $(n=246)$ indicated that they did not know whether their institution had difficulty recruiting visible minority librarians, followed by 35.7 percent $(n=162)$ who said no, and 10.1 percent $(n=46)$ who said yes. There were some positive responses in the "Other" category, with one respondent reporting "almost $1 / 3$ of our librarians are visible minorities" and another indicating that "roughly $25 \%$ of librarians so happen to be visible minorities." These responses were not typical, with many comments indicating that "there is no effort to recruit visible minority librarians" or that there has been "very little hiring." One respondent indicated that "many are from non-Canadian places and too often don't have proper accreditation for working in Canada." One of the issues raised in Creating a Representative Library Workforce in Saskatchewan is the issue of foreign credentials and the "need to encourage new immigrants to join the library workforce, including identifying assessment processes for/recognition of foreign library credentials." ${ }^{39}$ As in illustrated in table 5, of the 65 respondents who answered the question regarding the biggest obstacles their library faces with respect to the recruitment of visible minority librarians, 50.8 percent $(n=33)$ indicated that this was due to a limited pool of qualified applicants.

While 43.5 percent $(n=199)$ of respondents felt that their institution should be doing more to reach out and encourage applications from visible minority librarians, 28.7 percent $(n=131)$ did not, and 27.8 percent $(n=127)$ replied they didn't know. A range of perspectives were reflected in the comments from "librarian workforce does not yet reflect our community makeup" to "our library seeks to hire the best qualified candidates, regardless of non-merit-based characteristics." With respect to retention, 39.3 percent $(n=181)$ responded that they did not have difficulty retaining visible minority librarians, while 35.2 percent $(n=162)$ responded that they did not know, followed by "not applicable" $(21.7 \% ; n=100)$, and then yes $(3.7 \% ; n=17)$. Of the relatively small number of respondents who answered this question, the geographical location of the institution was the primary reason why the library had difficulty retaining visible 
TABLE 5

Obstacles to the Recruitment of Visible Minority Librarians $(\mathrm{N}=65)$

\begin{tabular}{|l|c|c|}
\hline Obstacles to Recruitment & $\mathbf{n}$ & $\begin{array}{c}\text { Percentage of } \\
\text { Total Responses }\end{array}$ \\
\hline Limited pool of qualified applicants & 33 & $50.8 \%$ \\
\hline Geographical location of institution & 25 & $38.5 \%$ \\
\hline $\begin{array}{l}\text { Failure on the part of hiring committees to follow } \\
\text { Employment Equity/Affirmative Action Plan }\end{array}$ & 11 & $16.9 \%$ \\
\hline Staff attitudes & 12 & $18.5 \%$ \\
\hline Hiring freezes & 16 & $24.6 \%$ \\
\hline $\begin{array}{l}\text { Applicants choose not to self-identify/difficult to obtain } \\
\text { information from applicants regarding racial/ethnic identity }\end{array}$ & 22 & $33.8 \%$ \\
\hline Don't know & 12 & $18.5 \%$ \\
\hline Other & 10 & $15.4 \%$ \\
\hline
\end{tabular}

minority librarians $(63.2 \% ; \mathrm{n}=12)$, followed by "limited number of visible minority librarians on staff" (53.6\%; $n=10)$, "climate is not hospitable or welcoming" $(47.4 \%$; $\mathrm{n}=9)$, and "limited number of visible minority staff at the institution" (52.6\%; $n=8)$.

In response to the final question in this section of the survey, most respondents indicated that their library was a hospitable and welcoming place for visible minority librarians $(69.5 \% ; \mathrm{n}=315)$, followed by don't know $(21.4 \%$; $=97)$, not applicable $(4.6 \%$; $\mathrm{n}=21)$, and no $(4.4 \% ; \mathrm{n}=20)$. Again, there were a range of comments under "Other" ranging from "I hope so, but I don't really know" to "not necessarily a welcoming place for any new librarians." A notable response was "to some extent but there are no resources put in place for a visible minority person who is also a new immigrant to Canada. Two separate categories, in my view." This issue is addressed by Kumaran, who discusses the unique challenges faced by first-generation visible minorities who face greater challenges than second- and third-generation visible minorities. One major challenge that first-generation visible minorities face is the "cultural differences between themselves and their new host country." 40 As mentioned earlier, this group accounts for 75 percent of the immigrants arriving in Canada.

There were a large number of responses to the final open-ended question: "Is there anything you would like to share with respect to the recruitment and/or retention of Aboriginal or visible minority librarians at your institution or in general?" Several respondents indicated that there were no issues of racism at their institution - "there is a very nice atmosphere of inclusiveness for everyone here" and "it just occurred to me that we probably do have members of visible minorities in our complement of librarians. I have never even thought of them as different [from] anyone else-they are just my colleagues." However, as pointed out by Edith Maureen Fisher, "[a] wareness of prejudice is not simply influenced by having a positive racial attitude. Lack of awareness of prejudice may contribute to denial that race has any impact and thereby impede racial understanding and communication, foster environments where individuals and their institutions are prone to act in negative discriminatory ways, and contribute to maintaining racism by being unable to acknowledge its existence." ${ }^{41}$ As will be revealed later, visible/racial minority librarian respondents reported experiencing racism and a lack of support for diversity. The comments of a select few respondents revealed hostility to what was perceived as preferential treatment for librarians from equity-seeking groups (non-Caucasian) and a bias 
against white male librarians. A barrier in the faculty hiring process and one of the obstacles encountered by faculty members from underrepresented racial and ethnic groups identified by the American Federation of Teachers is a "persistent opposition to affirmative action efforts" because of a "lingering perception that affirmative action somehow confers an unfair advantage to candidates from underrepresented groups." ${ }^{42}$ Of the 116 comments in the open-ended section, 18 respondents indicated that there was no effort made to recruit Aboriginal and visible/racial minority librarians at their institutions and that it was not a priority, while 16 respondents stressed that no preferential treatment should be given to these groups and that the most qualified applicant should be hired. The next greatest number of responses (n $=5$ ) related to the inhospitable climate for librarians identifying as visible minority followed by limited pool of qualified applicants $(n=4)$. Some of the issues raised in earlier responses were addressed again, such as "many Aboriginal people don't have the option/opportunity to go into undergraduate studies, let alone graduate studies" and "provincial education does not provide Aboriginal students with the education needed to succeed at university." With respect to the situation of new immigrants, "an Aboriginal or visible minority librarian may survive if $s /$ he is part of the greater or common Canadian culture," wrote one respondent. "However, the needs of a visible minority librarian who is also an immigrant are different. S/he will require more time to integrate. More mentoring and coaching are required to become part of the library community." Regarding the lack of visible minority librarians in leadership positions, another respondent wrote, "[t]hey are rarely recruited and rarely promoted. In one of the most ethnically and racially diverse cities in Canada, there are no African-Canadian librarians, and virtually no visible minorities in senior management positions, a situation which I personally find shocking." Finally, there is the issue of perceived racism and bias. "I've been at this institution for over ten years, and I really get the sense that librarian hiring committees keep hiring themselves over and over again (read: white, middle class women). It's frustrating, most especially because we really need to reflect in our own professional ranks the student population(s) we serve. I don't think this is going to change for a long time, at least not until newer librarians who are more sensitive to equity issues move into senior management positions." An Aboriginal librarian notes that the recruitment and/or retention of Aboriginal or visible minority librarians "is not discussed much, not a priority, less visible in library planning than in campus policy and planning" and that the "diversity of student and faculty population is greater than that of the library." One visible minority librarian posed the following question: "As a visible minority, I feel more welcome on campus to see many students of colour. Can I assume that students of colour would feel more welcome in the library if they were to see greater race diversity in the staff?"

\section{Part 2 (i)-Aboriginal Librarians}

There were only 6 Aboriginal respondents. Given the small number of respondents, no background information will be provided that may identify the respondents. Given the small number of respondents, it is also difficult to draw conclusions.

\section{Hiring and Self-identification}

The majority of respondents $(n=4)$ indicated that they were not made aware of an Employment Equity/Affirmative Action policy when they applied for [their] position. ${ }^{43}$ The 2 respondents who were made aware were sent information about the policy/a self-identification form after submitting their application. Both self-identified as Aboriginal. 


\section{Institutional Support}

When asked whether they had participated in any equity-related programs at their institutions, 3 had participated in equity-related presentations, 2 were members of an equity-related caucus, 2 were members of an equity-related listserv, one had participated in an equity-related workshop, one was the recipient of equity-related financial support including scholarships, and one had participated in informal equity-related gatherings. No respondents indicated that they had participated in equity-related leadership training, and no respondents indicated that they were recipients of a postMLS equity-related residency/internship/fellowship.

When asked if there are there any equity-related programs they would like to see offered by their library/institution, one respondent indicated yes, "some based on positive development as well as or instead of compliance or hiring; ones that look at diversity as a strength instead of a service gap or problem group needing accommodation. For example, see faculty who are not native English speakers as multilingual faculty, acknowledging their additional skills instead of seeing them as having less skills in English."

\section{Mentoring}

Only 2 respondents indicated that they had been mentored, and, in both cases, this was an informal mentoring relationship. Under "Other," one respondent indicated that most mentoring had taken place outside his/her institution. One respondent indicated that he/she was able to choose his/her own mentor; the other did not. In both cases, the mentor was a senior colleague of the same gender but not Aboriginal. With respect to ranking the mentoring experience, one respondent found it very helpful with respect to career counselling/information/advice and emotional support, while the other respondent found it somewhat helpful in both areas.

\section{Disadvantaged}

When asked if being an Aboriginal librarian was a disadvantage, one respondent reported being somewhat disadvantaged with respect to each of the following: salary, ability to participate fully in departmental meetings, and ability to participate fully in library meetings. No respondents reported being disadvantaged with respect to hiring, impact on tenure and promotion, evaluation for awarding of internal research grants, evaluation for awarding of merit awards, assignment of workload, evaluation of research/ scholarship, consideration for an administrative role or advancement, consideration for library committees or working groups, or professional development opportunities.

\section{Climate}

As is illustrated in tables 6 and 7, respondents ranked departmental climate slightly lower than that of climate in the library outside the department in several areas.

A total of three respondents answered the question regarding what steps their library can take to improve the climate with respect to diversity. Two respondents indicated that the library should provide staff diversity training and development; two indicated that management/administration should provide leadership with respect to diversity issues; two respondents indicated that the library should hire more diverse staff; and one respondent indicated that the library should provide social/cultural programs to increase awareness of diversity.

\section{Library Associations}

A total of 4 respondents belonged to a national, provincial, or special library association. No one indicated that they were not welcomed, not treated with respect or 


\begin{tabular}{|l|c|c|c|c|}
\hline \multicolumn{5}{|c|}{ TABLE 6 } \\
\multicolumn{4}{|c|}{ Perceptions of Departmental Climate by Aboriginal Respondents (N = 6) } \\
\hline $\begin{array}{l}\text { Perceptions of Departmental } \\
\text { Climate }\end{array}$ & \multicolumn{3}{|c|}{ Percentage of Total Responses (n) } \\
\cline { 2 - 5 } & Yes & Somewhat & No & N/A \\
\hline $\begin{array}{l}\text { I am treated with respect and accepted } \\
\text { as an equal member by colleagues in } \\
\text { my department }\end{array}$ & $83.3 \%(5)$ & $16.7 \%(1)$ & $0.0 \%(0)$ & $0.0 \%(0)$ \\
\hline $\begin{array}{l}\text { My knowledge and work contributions } \\
\text { are valued by colleagues in my } \\
\text { department }\end{array}$ & $66.7 \%(4)$ & $33.3 \%(2)$ & $0.0 \%(0)$ & $0.0 \%(0)$ \\
\hline $\begin{array}{l}\text { Colleagues in my department welcome } \\
\text { difference and value diversity }\end{array}$ & $66.7 \%(4)$ & $33.3 \%(2)$ & $0.0 \%(0)$ & $0.0 \%(0)$ \\
\hline $\begin{array}{l}\text { I feel free to speak my mind and } \\
\text { express my views openly amongst } \\
\text { colleagues in my department }\end{array}$ & $66.7 \%(4)$ & $16.7 \%(1)$ & $16.7 \%(1)$ & $0.0 \%(0)$ \\
\hline
\end{tabular}

accepted as an equal member, or that their knowledge and professional contributions were not valued. In the "Other" responses category, one respondent indicated being "not treated any different" and that "being Aboriginal has nothing to do with being welcomed, respected, valued." No respondents indicated that they had participated in any programs for Aboriginal librarians sponsored by a library association or another organization. When asked how library associations can support Aboriginal librarians, one respondent indicated that they should sponsor equity-related conferences/workshops, and one indicated that they should provide leadership with respect to equity issues. In the "Other" responses, one respondent suggested "get them involved and promote getting an MLIS" and another suggested "hire them for association work."

\begin{tabular}{|l|c|c|c|c|}
\hline \multicolumn{5}{|c|}{ TABLE 7 } \\
\multicolumn{4}{|c|}{$\begin{array}{l}\text { Perceptions of Climate in the Library outside Department by Aboriginal } \\
\text { Respondents (N = 6) }\end{array}$} \\
\hline $\begin{array}{l}\text { Perceptions of Climate outside } \\
\text { Department }\end{array}$ & \multicolumn{2}{c|}{ Percentage of Total Responses (n) } \\
\cline { 2 - 5 } $\begin{array}{l}\text { I am treated with respect and accepted } \\
\text { as an equal member by colleagues in the } \\
\text { library outside my department }\end{array}$ & $83.3 \%(5)$ & $16.7 \%(1)$ & $0.0 \%(0)$ & $0.0 \%(0)$ \\
\hline $\begin{array}{l}\text { My knowledge and work contributions are } \\
\text { valued by colleagues in the library outside } \\
\text { my department }\end{array}$ & $83.3 \%(5)$ & $16.7 \%(1)$ & $0.0 \%(0)$ & $0.0 \%(0)$ \\
\hline $\begin{array}{l}\text { Colleagues in the library outside my } \\
\text { department welcome difference and value } \\
\text { diversity }\end{array}$ & $83.3 \%(5)$ & $16.7 \%(1)$ & $0.0 \%(0)$ & $0.0 \%(0)$ \\
\hline $\begin{array}{l}\text { I feel free to speak my mind and express } \\
\text { my views openly in the library outside my } \\
\text { department }\end{array}$ & $83.3 \%(5)$ & $0.0 \%(0)$ & $16.7 \%(1)$ & $0.0 \%(0)$ \\
\hline
\end{tabular}


Part 2 (ii)_Visible Minority Librarians As is illustrated in table 8, 60 respondents identified as visible minority. Race/ethnic identity is grouped according to Statistics Canada classifications. ${ }^{44}$ The highest number of respondents identified as Chinese, reflecting the 2006 Canadian Census.

The majority of respondents $(73.3 \%$; $\mathrm{n}=44$ ) indicated that they came from a large institution (more than 24,000 full-time students); 20 percent of respondents $(n=12)$ came from mediumsized institutions (between 12,000 and 24,000 students); and the remaining 6.7 percent $(n=4)$ came from small institutions (less than 12,000 full-time students). Reflecting the distribution of the visible minority population in the Census, 76.7 percent $(n=46)$ indicated that their institution was located in a city with a population greater than 500,000 , and 16.7 percent $(n=10)$ indicated that their institution was located in a city or town with a population between 150,000 and 500,000. The remaining 6.7 percent $(n=4)$ were employed by institutions located in a city or town with a population of less than 150,000. More than 8 in $10(81.7 \% ; n=49)$ respondents were female. The majority $(77.2 \% ; n=44)$ worked in Reference/Instructional Services, with the second largest group $(47.4 \% ; n=27)$ working in Collection Development/Collection Management. Only 10.5 percent $(n=6)$ indicated that they worked in Administration, compared to 20.9 percent $(n=78)$ of respondents who did not identify as Aboriginal or visible minority-although this latter group reported more years of service to their institution and more years of professional experience. The findings mirror the 8Rs Report, which found that "with respect to career advancement there appears to be a lack of promotion opportunities for minority librarians in Canada." ${ }^{\prime 5}$

The largest group of respondents had been employed at their institution for less than 5 years $(45 \% ; n=27)$, followed by 25 percent $(n=15)$ reporting between $6-10$ years of experience. With respect to years of professional experience, the largest group reported between $6-10$ years of experience $(28.3 \%$; $n=17)$ followed by less than 5 years of experience $(26.7 \% ; n=16)$. The findings suggest an upward trend in hiring of visible minority librarians over the last ten years.

\section{Hiring and Self-identification}

Over a third $(36.8 \% ; \mathrm{n}=21)$ of respondents indicated that they were made aware of an Employment Equity/Affirmative Action policy when they applied for their position. Nearly as many $(35.1 \% ; n=20)$ were not made aware of it, and 22.8 percent $(n=13)$ did not remember. Of the 21 respondents who said they were made aware of such a policy, 12 respondents indicated that they were sent information about the policy/a self-identification form after submitting their application; 6 respondents indicated that they had noticed it in the job posting; 5 respondents indicated that they were told about the policy/invited to self-identify during the interview process by the hir- 
ing committee; and 2 did not remember. A total of 14 respondents indicated that they had self-identified as visible minority; 6 did not. Of those who did not self-identify, 6 respondents indicated that it was because they wanted to be hired on their own merit; 2 indicated that they did not think it was important; and one indicated that they did not believe that it would make a difference. Under "Other," one respondent indicated that it was obvious; one indicated that there was no need to do so; and one indicated that "If I had to do it again, I would have self-identified." Yet one librarian wrote in the final comments section: "Self-identifying as a visible minority when I applied for my position haunts me to this day. I feel that others regard my getting the position based on affirmative action. I feel the pressure to prove myself every day. I feel that my white counterparts do not have the same kind of pressure."

\section{Institutional Support}

As is illustrated in table 9, when asked whether they had participated in any equity-related programs at their institutions, the two most frequently attended programs were equityrelated workshops $(n=17)$ and equity-related presentations $(n=17)$. No respondents indicated that they were recipients of a post-MLS equity-related residency/internship/ fellowship. When asked if there was anything they would like to share regarding these programs, one respondent suggested that "there should be a workplace policy aside from repeated programs, especially from the top administration to create an environment that supports non-bias equity treatment for both white and non-white librarians," and another requested "please increase the awareness of diversity and come up with programs to support visible minority librarians who face discriminatory situations."

\begin{tabular}{|c|c|c|c|}
\hline \multicolumn{4}{|c|}{$\begin{array}{c}\text { TABLE } 9 \\
\text { Participation in Library/Institution Equity-Related Programs by Visible } \\
\text { Minority Respondents }(\mathrm{N}=57)\end{array}$} \\
\hline \multirow[t]{2}{*}{ Participation in Equity Related Programs } & \multicolumn{3}{|c|}{ Percentage of Total Responses (n) } \\
\hline & Yes & No & N/A \\
\hline Equity-related workshops & $29.8 \%(17)$ & $66.7 \%(38)$ & $3.5 \%(2)$ \\
\hline Equity-related presentations & $32.1 \%(17)$ & $64.2 \%(34)$ & $3.8 \%(2)$ \\
\hline Equity-related leadership training & $4.3 \%(2)$ & $85.1 \%(40)$ & $10.6 \%(5)$ \\
\hline $\begin{array}{l}\text { Recipient of equity-related financial support } \\
\text { including scholarships }\end{array}$ & $2.2 \%(1)$ & $87.0 \%(40)$ & $10.9 \%(5)$ \\
\hline $\begin{array}{l}\text { Recipient of post-MLS equity-related residency/ } \\
\text { internship/fellowship }\end{array}$ & $0.0 \%(0)$ & $89.1 \%(41)$ & $10.9 \%(5)$ \\
\hline Member of an equity-related caucus & $22.9 \%(11)$ & $68.8 \%(33)$ & $8.3 \%(4)$ \\
\hline $\begin{array}{l}\text { Member of an equity-related listserv/discussion } \\
\text { list }\end{array}$ & $12.8 \%(6)$ & $76.6 \%(36)$ & $10.6 \%(5)$ \\
\hline Informal equity-related gatherings & $21.3 \%(10)$ & $72.3 \%(34)$ & $6.4 \%(3)$ \\
\hline Other & $5.26 \%(3)$ & $0.0 \%(0)$ & $0.0 \%(0)$ \\
\hline
\end{tabular}

When asked if there were there any equity-related programs they would like to see offered by their library/institution, respondents replied as follows:

- "Workshops, presentations to be repeated now and then, and also equity policy for non-bias treatment of all staff."

- "Not familiar enough with them to say, but certainly something that increases 
colleagues' awareness of ethnic minorities and relevant issues... and increases their sensitivity."

- "Diversity and sensitivity training as part of an overall, stated, institutional human resources strategy-including focus on aboriginal issues and sexual diversity."

- "The university actively recruits minority and international students. I would like the library to be as involved with these students as are other areas of the university such as the International Students Office, the Student Career Office and the Writing Centre."

- "Basic awareness raising programs might be useful."

- "I would be interested in learning more about the minorities' experience in leadership positions."

- "All of the above; especially the equity-related workshops for ALL library staff."

- "An orientation where both majority and minority cultures play games and get to know the differences in each other."

- "Awareness of diversity issues."

\section{Mentoring}

Nearly one-third $(32.1 \% ; \mathrm{n}=18)$ of respondents indicated that they had been mentored, and 14 of those respondents indicated that this was an informal mentoring relationship. More than half $(n=10)$ were able to choose their own mentor. In most cases $(n=15)$, the mentor was a senior colleague and of the same gender $(n=11)$. Only 4 responded that the mentor was a visible minority (the same number who reported that the mentor was a Department Head/Administrator). When asked to rank their mentoring experience, 9 respondents found it very helpful with respect to career counselling, 7 found it somewhat helpful, and 3 found it not helpful. With respect to emotional support, 6 respondents found it very helpful, 4 respondents found it somewhat helpful, 4 respondents found it not helpful, and 5 indicated "not applicable." When asked if there was anything they would like to share regarding their mentoring experience, one respondent commented as follows:

"I realised that in this particular job I needed a mentor who was not only a go-to person for library information but one who was a coach - who would be accessible and one [who] would not wait for me to make the first move since I was often not aware of what I needed to know. I needed someone who could help me integrate culturally and one who was nurturing and empowering."

Damasco and Hodges report that "[i]nformal mentoring was cited by the highest number of respondents ( $56.7 \%$ ) as an effective form of professional development. Only 30 percent rated formal mentoring as effective, and a nearly equivalent number of respondents $(28.3 \%)$ rated it as an ineffective form of development. One explanation for the difference between perceptions of informal and formal mentoring could be the very nature of the relationship between the mentee and mentor. Informal mentoring situations may arise when two individuals find they have a positive working relationship that is built upon mutual interests or compatible personality types. Formal mentoring situations may backfire if a mentor and mentee are involuntarily paired and fail to develop a good working relationship." ${ }^{46}$

\section{Disadvantaged}

As is illustrated in table 10, when asked whether they had been disadvantaged as a visible minority librarian, the majority responded that they had not, yet a significant 


\begin{tabular}{|l|c|c|c|c|}
\hline \multicolumn{5}{|c|}{ TABLE 10 } \\
\hline \multirow{2}{*}{ Areas Disadvantaged as a Visible Minority Librarian (N = 57) } \\
\cline { 2 - 5 } & \multicolumn{2}{|c|}{ Percentage of Total Responses (n) } \\
\hline Hiring & $9.3 \%(5)$ & $9.3 \%(5)$ & $81.5 \%(44)$ & $0.0 \%(0)$ \\
\hline Salary & $5.5 \%(3)$ & $7.3 \%(4)$ & $87.3 \%(48)$ & $0.0 \%(0)$ \\
\hline Impact on tenure and promotion & $8.9 \%(5)$ & $3.6 \%(2)$ & $73.2 \%(41)$ & $14.3 \%(8)$ \\
\hline $\begin{array}{l}\text { Evaluation for awarding of internal } \\
\text { research grants }\end{array}$ & $5.4 \%(3)$ & $5.4 \%(3)$ & $62.5 \%(35)$ & $26.8 \%(15)$ \\
\hline $\begin{array}{l}\text { Evaluation for awarding of merit } \\
\text { awards }\end{array}$ & $7.1 \%(4)$ & $5.4 \%(3)$ & $73.2 \%(41)$ & $14.3 \%(8)$ \\
\hline Assignment of workload & $5.5 \%(3)$ & $9.1 \%(5)$ & $81.8 \%(45)$ & $3.6 \%(2)$ \\
\hline Evaluation of research/scholarship & $7.3 \%(4)$ & $3.6 \%(2)$ & $70.9 \%(39)$ & $18.2 \%(10)$ \\
\hline $\begin{array}{l}\text { Consideration for an administrative } \\
\text { role or advancement }\end{array}$ & $11.1 \%(6)$ & $7.4 \%(4)$ & $64.8 \%(35)$ & $16.7 \%(9)$ \\
\hline $\begin{array}{l}\text { Consideration for library } \\
\text { committees/working groups }\end{array}$ & $13.0 \%(7)$ & $5.6 \%(3)$ & $75.9 \%(41)$ & $5.6 \%(3)$ \\
\hline $\begin{array}{l}\text { Ability to participate fully at } \\
\text { departmental meetings }\end{array}$ & $5.6 \%(3)$ & $5.5 \%(3)$ & $83.6 \%(46)$ & $5.5 \%(3)$ \\
\hline $\begin{array}{l}\text { Ability to participate fully at library } \\
\text { meetings }\end{array}$ & $8.9 \%(5)$ & $5.4 \%(3)$ & $83.9 \%(47)$ & $1.8 \%(1)$ \\
\hline $\begin{array}{l}\text { Professional development } \\
\text { opportunities }\end{array}$ & $3.8 \%(2)$ & $7.5 \%(4)$ & $86.8 \%(46)$ & $1.9 \%(1)$ \\
\hline
\end{tabular}

number indicated that they had been disadvantaged or somewhat disadvantaged. The two areas where respondents had felt most disadvantaged were consideration for an administrative role or advancement and consideration for library committees/working groups. A total of 10 respondents out of 57 indicated that they were disadvantaged or somewhat disadvantaged in these areas combined, representing a response rate of approximately 18 percent.

\section{Climate}

As is illustrated in table 11, with respect to departmental climate, there were areas that were ranked low. Out of 57 respondents, a significant number indicated that their colleagues did not or only somewhat welcomed difference and valued diversity $(42.8 \%$; $n$ $=24$ ) and that they did not feel free to speak their mind and express their views openly (38.6\%; $n=22$ ). Meanwhile, a lesser but still significant number indicated that they were not or only somewhat treated with respect and accepted as an equal member $(23.3 \% ; n=13)$ and did not feel or only somewhat felt that their knowledge and work contributions were valued by colleagues $(16.1 \% ; n=9)$.

As is illustrated in table 12, with respect to climate outside their department, responses were less positive. Nearly half $(47.2 \%$; $=25)$ of respondents reported that their colleagues only somewhat or did not welcome difference and value diversity, followed by 39.6 percent $(n=21)$ of respondents who only somewhat or did not feel free to speak their mind and express their views openly. Furthermore, 31.8 percent (n $=16$ ) of respondents somewhat or did not feel treated with respect and accepted as an equal member, and somewhat or did not feel that their contributions were valued. 


\begin{tabular}{|c|c|c|c|c|}
\hline \multicolumn{5}{|c|}{$\begin{array}{c}\text { TABLE } 11 \\
\text { Perceptions of Departmental Climate by Visible Minority Respondents } \\
(\mathrm{N}=57)\end{array}$} \\
\hline \multirow{2}{*}{$\begin{array}{l}\text { Perceptions of Departmental } \\
\text { Climate }\end{array}$} & \multicolumn{4}{|c|}{ Percentage of Total Responses (n) } \\
\hline & Yes & Somewhat & No & $\mathrm{N} / \mathrm{A}$ \\
\hline $\begin{array}{l}\text { I am treated with respect and } \\
\text { accepted as an equal member by } \\
\text { colleagues in my department }\end{array}$ & $76.8 \%(43)$ & $17.9 \%(10)$ & $5.4 \%(3)$ & $0.0 \%(0)$ \\
\hline $\begin{array}{l}\text { My knowledge and work } \\
\text { contributions are valued by } \\
\text { colleagues in my department }\end{array}$ & $83.9 \%(47)$ & $10.7 \%(6)$ & $5.4 \%(3)$ & $0.0 \%(0)$ \\
\hline $\begin{array}{l}\text { Colleagues in my department } \\
\text { welcome difference and value } \\
\text { diversity }\end{array}$ & $57.1 \%(32)$ & $32.1 \%(18)$ & $10.7 \%(6)$ & $0.0 \%(0)$ \\
\hline $\begin{array}{l}\text { I feel free to speak my mind and } \\
\text { express my views openly amongst } \\
\text { colleagues in my department }\end{array}$ & $61.4 \%(35)$ & $24.6 \%(14)$ & $14.0 \%(8)$ & $0.0 \%(0)$ \\
\hline
\end{tabular}

The findings mirror those of Domasco and Hodges with respect to organizational climate and culture, where 31.7 percent of respondents felt that they "could not freely voice their opinions at their library." ${ }^{47}$

\begin{tabular}{|l|c|c|c|c|}
\hline \multicolumn{5}{|c|}{ TABLE 12 } \\
\multicolumn{5}{|c|}{$\begin{array}{c}\text { Perceptions of Climate in the Library outside Department by Visible } \\
\text { Minority Respondents (N = 54) }\end{array}$} \\
\hline \multirow{2}{*}{$\begin{array}{l}\text { Perceptions of Climate outside } \\
\text { Department }\end{array}$} & \multicolumn{2}{|c|}{ Percentage of Total Responses (n) } \\
\hline $\begin{array}{l}\text { I am treated with respect and accepted } \\
\text { as an equal member by colleagues in } \\
\text { the library outside my department }\end{array}$ & $67.3 \%(35)$ & $28.8 \%(15)$ & $1.9 \%(1)$ & $0.0 \%(0)$ \\
\hline $\begin{array}{l}\text { My knowledge and work contributions } \\
\text { are valued by colleagues in the library } \\
\text { outside my department }\end{array}$ & $67.9 \%(36)$ & $26.4 \%(14)$ & $3.8 \%(2)$ & $1.9 \%(1)$ \\
\hline $\begin{array}{l}\text { Colleagues in the library outside my } \\
\text { department welcome difference and } \\
\text { value diversity }\end{array}$ & $49.1 \%(26)$ & $41.5 \%(22)$ & $5.7 \%(3)$ & $3.8 \%(2)$ \\
\hline $\begin{array}{l}\text { I feel free to speak my mind and } \\
\text { express my views openly in the library } \\
\text { outside my department }\end{array}$ & $58.5 \%(31)$ & $30.2 \%(16)$ & $9.4 \%(5)$ & $1.9 \%(1)$ \\
\hline
\end{tabular}

When asked whether there was anything they would like to share regarding their experience as a visible minority librarian in their department and/or library, the following responses offer some insights:

- "Think the Main Library of the University needs to allow and encourage participatory management and governance, so that minority heads of departments can contribute to governing decisions affecting their department." 
- "There is no colleague sensitivity to any differences I may have in communications, experience or working style, due to my ethnic minority... Neither my library nor my institution have the ratio of employees of ethnic minorities that anywhere equals/reflects the diverse multicultural composition of our institution, province or country."

- "I am still very much a minority; and there are NO aboriginal librarians in my larger institution."

- "It is lonely! For the first time in my entire life I have felt that I belong to a minority and yet I am in a kind and safe environment and my colleagues would be hurt and perplexed if I were to tell them this."

- "My experience has been generally positive. It is perhaps easy when you are the only minority - visible or otherwise, to want to read things into what is said and done around you. I have learnt that as a proud black woman, I do not need to read people's actions as I am very capable of picking out any behaviour that would suggest anything negative. Perhaps because of this, I have been able to have good working relationships in all my years here."

- "When it comes to elections for librarians on committees, if I put my name forward I always have to wonder if the other [visible minority] librarian is putting their name forward. If we both put our names forward chances are that neither of us will get elected. I have been a librarian at my institution for more than 5 years and other library staff members still confuse me with the other [visible minority] librarian. I've been on a search committee of 5 people (the only visible minority) and the Chair never recognized me outside of this context (e.g. on the bus). It gets pretty lonely being an invisible visible minority!"

- "II find the Christmas customs uncomfortable."

- "I have been in my job for less than a year. I feel welcome, but cannot really speak to what others think or feel about my presence or my contributions. I enjoy my work and feel that I have been fully encouraged to do whatever I see fit in my position."

- "Face racially inappropriate comments."

One theme that emerges in the comments is that of loneliness and isolation. Karen Downing indicates that "the sense of isolation and loneliness that can arise from repeatedly being the only person of color in the room can be stressful" and that "being the only one" can bring a "distinct set of hurdles and isolating feelings to some work experiences." ${ }^{48}$ The Damasco and Hodges study revealed that 40 percent of respondents "indicated feelings of isolation," and one third felt "excluded from informal networks at their libraries." ${ }^{49}$ One respondent indicated that the climate had improved "only very recently, when my library hired another person who is an ethnic minority."

Regarding what steps their library can take to improve the climate with respect to diversity, 73.3 percent $(n=33)$ indicated that the library should provide staff diversity training and development; 64.4 percent $(n=29)$ indicated that the library should provide social/cultural programs to increase awareness of diversity; 60 percent $(n=27)$ indicated that management/administration should provide leadership with respect to diversity issues; 60 percent $(n=27)$ of respondents indicated that the library should conduct a diversity climate assessment; and 55.6 percent $(n=25)$ indicated that the library should hire more diverse staff.

In response to the open-ended question as to how their library could better support them as a visible minority librarian, the most frequently cited response was "mentorship" and "mentoring programs" $(n=4)$. A number of respondents indicated that they were already supported. One wrote: 
"I am now in the dusk of my career and this library has supported me throughout my career. I hope and trust that any other visible minorities hired after my departure will be able to look back when they get to the dusk of their careers feeling as good about the place as I do."

Yet the following comments were also received, providing insight into how academic libraries and academic librarian colleagues can better support visible/racial minority librarians:

- "By encouraging participatory governance, and putting in cultural awareness events and programs now and then."

- "At this point, I'm not sure that they can... but acknowledging me as an ethnic minority would be a start. Learning to communicate and work with me more sensitively would be another ...my colleagues are very Eurocentric and expect that everyone has the same biases and perspectives in this regard. Sensitivity needs to be exercised.... When I was first hired, it took most of my colleagues several years before they bothered to learn how to pronounce my last name correctly ... This was extremely insulting, but they didn't think it was of any importance...."

- "Allow for overseas trips to 'homelands' which take unusual lengths of time, and other kinds of allowances for such cultural challenges."

- "By giving public recognition."

- "Acknowledge that my experience as a visible minority librarian might be different [from] the 'normal' one. Make others aware of the diversity plan and actually follow through on the plan!"

- 'I don't think formal workshops/training would be appreciated by most staff members. But having more acknowledgement that the library staff is diverse and celebrating and acknowledging that diversity might work. Right now, it feels like people just pretend on the surface that everyone is the same and treated the same way. And it doesn't really play out that way."

- "Strong management decision to hire more visible minority."

\section{Library Associations}

There is a fairly high rate of participation of visible minority librarians in library associations in Canada. Nearly half $(46.8 \% ; n=22)$ report current membership in a national library association; 56.8 percent $(n=25)$, in a provincial library association; and 46.2 percent $(n=18)$, in a special library association. When asked about their experience when participating in selected library association activities (conferences/workshops, committees/working groups, caucus/special interest group, listserv/discussion list), no respondents indicated that they were not welcomed or that their knowledge and professional contributions were not valued. However, in all activities, feeling welcomed ranked higher than being treated with respect and accepted as an equal member, and knowledge and professional contributions valued.

When asked whether there was anything they would like to share regarding their experience as a visible minority librarian participating in library association activities in Canada, the following responses were received:

- "Would be nice to see more diversity."

- "I have presented papers at my provincial association and also attended national conferences and my experiences have all been positive."

- "We need to do more to support visible minority librarians - like they do in the US."

- "Visible minority presence is strong compared to associations in the USA 
(national level) but there is room for improvement in leadership capacities in these organizations."

- "Attending library association conferences in Canada, the invisibility of my experience is accentuated. There are not many visible minority librarians in Canada. Library conferences are the best place to observe this."

- "We don't have a minority library association such as the ones in US. For my research, I could not find the statistics on the number of minority librarians working in Canada - not even a ball park figure."

The areas where respondents felt that library associations in Canada could support visible minority librarians are illustrated in table 13 below.

\begin{tabular}{|l|c|c|}
\hline \multicolumn{3}{|c|}{ TABLE 13 } \\
\begin{tabular}{|l|c|} 
Areas where Library Associations in Canada Can Support Visible Minority \\
Librarians by Visible Minority Respondents (N = 48)
\end{tabular} \\
\hline $\begin{array}{l}\text { Library Association Support } \\
\text { n }\end{array}$ & $\begin{array}{c}\text { Percentage of } \\
\text { Total Responses }\end{array}$ \\
\hline Sponsor equity-related conferences & 23 & $47.9 \%$ \\
\hline Sponsor equity-related workshops & 33 & $68.8 \%$ \\
\hline Create equity-related committees/working groups & 27 & $56.3 \%$ \\
\hline Create equity-related caucuses & 22 & $45.8 \%$ \\
\hline Create equity-related listservs/discussion lists & 20 & $41.7 \%$ \\
\hline Create/provide opportunities for equity-related networking & 27 & $56.3 \%$ \\
\hline Create/provide opportunities for equity-related mentoring & 29 & $60.4 \%$ \\
\hline Provide leadership with respect to equity issues & 35 & $72.9 \%$ \\
\hline
\end{tabular}

In the "Other" response category, mentoring was again raised by 2 respondents. "Create library associations for diverse groups where we can mentor each other and invite others to come and mentor us," suggested one. Yet another wrote: "I'm not sure-as racism is deeply ingrained and is not something that can readily be eliminated by merely giving workshops, etc."

\section{Survey Summary and Limitations}

The study revealed a general unfamiliarity with equity plans and programs on the part of Canadian academic librarians. Barriers to the recruitment of Aboriginal and visible/ racial minority librarians include a lack of proactive hiring efforts and a shortage of qualified candidates, particularly as relates to Aboriginal librarians. Visible/racial minority librarians perceived the climate for diversity within their academic libraries as less positive than librarians who did not identify as visible/racial minority. A significant number of visible/racial minority librarians felt that their colleagues did not welcome difference or value diversity, that they did not feel free to speak their minds openly, and that they experienced feelings of isolation and loneliness. The study also revealed a lack of leadership with respect to racial and ethnic diversity both within academic libraries and the profession at large in Canada. The findings point to an absence of public discourse relating to racial and ethnic diversity in librarianship in Canadian academic libraries, LIS programs, and library associations. There is a need for more research into the issues that have been identified as well as proactive steps to address them. More specific recommendations are outlined below. 
It should be noted that the disparity in sample size in the first part of the survey makes it difficult to draw conclusions on the basis of any differences between responses from those who did not identify as either Aboriginal or visible/racial minority and those who identified as Aboriginal or visible minority. For the second part of the survey, it is acknowledged that without further study it is difficult to determine whether the findings can be directly attributed to Aboriginal or visible/racial minority status. With respect to climate and institutional support, librarians who did not identify as visible/ racial minority may perceive that their own working conditions are similar to those librarians who identified as visible/racial minority. Therefore, it must be recognized that the study is exploratory in nature and that further research is necessary. The need for further research should not, however, prevent the findings from being used to develop, inform, and strengthen diversity initiatives and programs at the institutional and library association level in Canada.

\section{Recommendations and Avenues for Further Research Data Gathering}

To fully understand the extent of the underrepresentation of Aboriginal and visible/ racial minorities among academic librarians and in LIS education in Canada, the study points to a clear need for current and comprehensive data. Data must also be made available at the institutional level so that academic libraries can measure their progress. In Achieving Racial and Ethnic Diversity among Academic and Research Librarians: The Recruitment, Retention, and Advancement of Librarians of Color, the "[c]reation, gathering, and maintenance of reliable and accurate demographic data for the professional overall and for academic librarians in particular" has been identified by ACRL as a strategic goal for increased racial and ethnic representation in librarianship..$^{50}$

\section{Institutional Leadership and Support}

There must be leadership as well as commitment to increasing racial and ethnic diversity among academic librarians in Canada at the institutional level. The Diversity Standards: Cultural Competency for Academic Libraries (2012) "provide a framework to support libraries in engaging the complexities of providing services to diverse populations, and recruiting and maintaining a diverse library workforce." The Standards can also "serve as a starting point from which libraries can develop local approaches and goals in the context of their organizations' mission and situation." ${ }^{51}$ Areas in need of attention at the institutional level identified in this study and discussed more fully below include education and training for professional staff; acknowledging the perceptions of racism and isolation experienced by racial and ethnic minority librarians; providing opportunities for administrative advancement; developing mentoring programs; and creating employment opportunities for Aboriginal and visible/racial minority students in academic libraries.

Better training and education with respect to employment equity plans and requirements under the Federal Contractors Program is necessary. Requirement 2 of the Federal Contractors Program stipulates clear expectations on the part of the Employer to all staff regarding communication around employment equity goals, measures, and progress. ${ }^{52}$ While communication may be taking place, it appears to be inadequate and not been understood by professional staff. Also, according to the 8Rs Report, " $t$ ] he limited sector variation in visible minority and aboriginal representation does not correspond with whether or not institutions have a hiring policy designed to recruit professionals from diverse ethnic and racial backgrounds... For example, compared to the total institutional sample where only $28 \%$ have such a policy, $77 \%$ of CARL [Canadian Association of Research Libraries] libraries report having a diversity policy, but 
their visible minority representation does not significantly depart from other sectors. These results suggest not only that libraries without diversity policies should consider implementing such a policy, but that those with a policy should look closely at how it is being implemented." ${ }^{53}$ The development and sharing of best practices with respect to the recruitment and retention of librarians from underrepresented groups would assist those libraries with less experience or limited success in this area. There are academic libraries, such as York University Libraries, which have had success in recruiting racial and ethnic minority librarians through the education and training of hiring committees and the development of a library Affirmative Action Plan. ${ }^{54}$ While hiring committees should ideally be diverse, this may be unrealistic at institutions where there are few librarians from underrepresented groups. Institutions need not, and should not, however, wait for institutional plans and collective bargaining protocols that require them to act.

There must be an acknowledgement that Aboriginal and visible/racial minority librarians perceive that racism exists and that more efforts need to be made to make these librarians feel valued for their differences and to ensure that they feel fully involved in their libraries. Diversity awareness training in the form of workshops should be provided and efforts made to create a welcoming environment for Aboriginal and visible/racial minority librarian colleagues. The isolation and loneliness experienced by racial and ethnic minority librarian colleagues must also be recognized.

The issue of underrepresentation of racial and ethnic minority librarians in administrative positions revealed in the study should be more closely examined and addressed. There are a number of leadership programs in the United States for racial and ethnic minority librarians that accept applications from qualified Canadians: ALA's Spectrum Initiative, the Minnesota Institute for Early Career Librarians of Color, and ARL's Leadership and Career Development Program. Financial assistance should be provided to encourage Canadian librarians to participate. As stated by Ashley E. Bonnette, a "truly diverse workforce is not fully present until it is represented equally throughout all levels of the organization, not only at entry- and mid-level positions, but throughout administrative ranks as well." 55 The creation of a leadership program in Canada should also be explored.

The development of effective mentoring programs for racial and ethnic minority librarians should also be pursued. As Linda Musser writes, "[a] common misconception about mentoring, however, is that people expect relationships simply to happen. There is a tendency for mentors to pair with someone similar to themselves. For a minority employee there may be no natural match; therefore the creation of a mentoring relationship may need some assistance on the part of the organization." Mentoring will help to address the feelings of isolation and loneliness on the part of racial and ethnic minority librarians and help them "understand the unwritten rules of the workplace and the cultural or organizational norms." 56

Some of the factors identified in studies that influence an individual's decision to enter the LIS field include "the intellectual and service-oriented characteristics of librarianship, role models (e.g. librarians and teachers), previous library work experience, and availability of financial aid. ${ }^{\prime 57}$ Meanwhile, previous library work experience ranked as the most influential factor in the decision to pursue LIS studies. ${ }^{58}$ While the employment equity programs at Canadian universities do not extend to casual/parttime staff, academic libraries should make efforts to hire racial and ethnic minority students for positions in the library.

\section{Library and Information Science Programs Recruitment}

While there may be challenges to increasing diversity in LIS programs, there are currently no formal initiatives in Canada to recruit Aboriginal and visible/racial 
minority librarians into LIS programs. The creation of scholarships and fellowships would facilitate growing the pool, which was identified in the study as an obstacle to recruitment of Aboriginal and visible/racial minority librarians in Canadian academic libraries. Kim and Sin identify the following top five recruitment strategies for increasing diversity in LIS: “(1) assistantship/scholarship/financial aid, (2) ethnic diversity in faculty, (3) role models from ethnic groups, (4) presence of faculty/staff of color in the recruitment process, and (5) opportunities to work in the LIS-related fields." ${ }^{59}$ Ontario and the four western provinces (British Columbia, Alberta, Manitoba, Saskatchewan) have the highest aboriginal populations. ${ }^{60}$ According to Creating a Representative Library Workforce in Saskatchewan, "38\% of libraries located in Saskatchewan and Manitoba experience problems recruiting" and that "[s]ince there are no library science programs in either province, libraries are often faced with the task of attracting librarians out of province." It suggests that "[a] successful diversity strategy would find candidates in underutilized segments of Saskatchewan's existing population" by creating a bursary "to encourage Aboriginal people and members of other diversity groups to pursue library-related education." 61 There is a pressing need for LIS programs to be proactive in addressing the challenges of recruiting Aboriginal librarians through the development of online education. Increased diversity in LIS faculty must also be pursued. As Lisa K. Hussey points out, "[a]cross LIS programs there is little agreement regarding methods to encourage ethnic minorities into librarianship. The focus is primarily on students with little attention paid to the diversity of faculty and staff within LIS programs." 62

\section{Library Association Leadership and Support}

Library associations in Canada must demonstrate greater leadership with respect to diversity, including the development of standards and programs. Racial and ethnic minority caucuses modeled on those in the United States would provide leadership and advocacy from within communities of racial and ethnic minority librarians in Canada and provide mentoring and networking opportunities. The recent creation of the Visible Minority Librarians of Canada Network (ViMLoC) has been an important step in this direction. ${ }^{63}$ As pointed out by Tami Echavarria and Andrew B. Wertheimer, "[e] thnic associations provide a sense of community and networking for their members" and can be "a voice of unity for its constituents." 64

\section{Conclusion}

As is pointed out by Kim and Sin, "[t]he benefits of ethnic diversity in the LIS field are multifold: it benefits library users, library organizations, and LIS programs." Furthermore, "[d]iversity in higher education can foster intellectual development, reduce students' level of racial prejudice, and facilitate students' explorations of diverse perspectives." ${ }^{65}$ Addressing the underrepresentation of Aboriginal and visible/racial minority librarians among academic librarians in Canada is a shared commitment and responsibility. In the words of Downing, Alire and Cawthorne, "the profession has a responsibility to [ensure] that the next generation of library leaders more closely reflects the populations their library institutions serve."66 


\section{CANADIAN ACADEMIC LIBRARIANS DIVERSITY SURVEY}

\section{CANADIAN ACADEMIC LIBRARIANS DIVERSITY SURVEY}

You are being invited to participate in a survey relating to diversity and academic librarians in Canada. The purpose of this survey is to gather information regarding recruitment and retention practices for academic librarians from equity seeking groups in Canada. It is also seeking to better understand the needs and experiences of Aboriginal and visible minority librarians employed in Canadian academic libraries. The findings will contribute to original research in this area and will provide a foundation for further research. The results may also be used to develop, inform, and strengthen diversity initiatives and programs at the institutional and library association level in Canada.

The survey is divided into two parts. The first part is open to all academic librarians in Canada and takes approximately 10-15 minutes to complete. The second part is open to Aboriginal and visible minority academic librarians in Canada and takes approximately 15-20 minutes to complete. The survey will remain open until June 30, 2011.

Note: According to Section 3 of the Employment Equity Act, 1995, "'Aboriginal peoples' means persons who are Indians Inuit or Métis" and "'members of visible minorities' means people, other than Aboriginal peoples, who are non-Caucasian in race or non-white in colour." (http://laws-lois.justice.gc.ca/eng/acts/E-5.401/page-1.html)

\section{What is the size of the institution where you are employed?}

Small (less than 12,000 full-time students)

Medium (between 12,000 and 24,000 full-time students)

Large (more than 24,000 full-time students)

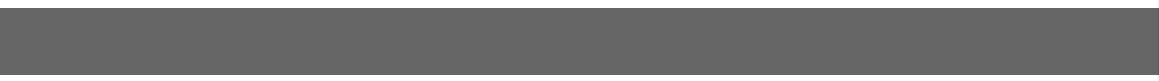

What is the population of the city or town where your institution is located?

Small (less than 150,000 )

Medium (between 150,000 and 500,000)

Large (greater than 500,000 )

How many years have you been employed by your present institution?
0-5 years
$6-10$ years
$11-15$ years
$15-20$ years
$20+$ years




\section{CANADIAN ACADEMIC LIBRARIANS DIVERSITY SURVEY}

How many years of professional librarian experience do you have in total?
0-5 years
6-10 years
11-15 years
16-20 years
$20+$ years

What rank do you currently hold?
Assistant Librarian
Associate Librarian
Librarian / Senior Librarian
Librarian $1 / 1$
Librarian 2/II
Librarian $3 /$ III
Librarian 4 / IV
Librarian $5 / \mathrm{V}$
Contractually Limited Librarian
Sessional Librarian

Other (please specify)

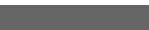
Female
$\bigcirc$ Male

What is your gender?

Other (please specify) 


\section{CANADIAN ACADEMIC LIBRARIANS DIVERSITY SURVEY}

\section{What area of the library best describes where you work? Please check all that are} applicable.

Acquisitions

$\square$ Administration

$\square$ Archives

Bibliographic Services / Cataloguing / Metadata

$\square$ Collection Development / Collection Management

Data / GIS

Digital Initiatives

Electronic Resources

I IT / Systems / Web Development

Rare Books / Special Collections

$\square$ Reference / Instructional Services

Specialized Unit (i.e., Maps, Media)

Other (please specify)

The Federal Contractors Program was established in 1986 to further the goal of achieving workplace equity for designated groups experiencing discrimination in the Canadian labour market. These groups are: women; Aboriginal peoples; persons with disabilities; and members of visible minorities. (http://www.hrsdc.gc.ca/eng/labour/equality/fcp/index.shtml)

Under the Federal Contractors Program organizations are required to establish an employment equity program that includes the creation of an employment equity plan that is intended to guide these organizations toward meeting employment equity goals.

Does your library have an Employment Equity / Affirmative Action Plan that outlines proactive measures or strategies for recruiting qualified librarians who are women, Aboriginal peoples, persons with disabilities, and members of visible minorities?

$\bigcirc$ Yes

$\bigcirc$ No

Don't know

Other (please specify) 


\section{CANADIAN ACADEMIC LIBRARIANS DIVERSITY SURVEY}

Is this a separate library plan or part of a broader institutional plan?

Separate library plan
Part of a broader institutional plan
Don't know
Other (please specify)

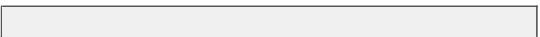

\section{How familiar are you with this plan?}

very

Somewhat

Not at all

Other (please specify)

How / where is this plan made available to librarians? Please check all that are applicable.

$\square$ Posted on the library / institution website

Posted on library staff website

Included in library staff handbook

Distributed to all new hires

$\square$ Distributed to all hiring committees

Don't know

Other (please specify) 


\section{CANADIAN ACADEMIC LIBRARIANS DIVERSITY SURVEY}

How often does your library follow this plan?

Always

Most of the time

Sometimes

Never

Don't know

Other (please specify)

Are any of the following included in your library's plan or in a separate library document?

Statement of diversity /

equity values or goals for

Yes

No

Don't know

Not applicable

the library

Outline of library programs

that promote diversity or

$\bigcirc$

$\bigcirc$

$\bigcirc$

ethnic / cultural sensitivity

in the workplace

Strategies for retention and

support of librarians from

equity-seeking groups after

they are hired

Other (please specify) 


\section{CANADIAN ACADEMIC LIBRARIANS DIVERSITY SURVEY}

Is there anyone responsible for overseeing programs or training relating to diversity I equity in the library? Please check all that are applicable.

$\square$ Diversity / Equity / Affirmative Action Office(r)

Diversity / Equity / Affirmative Action Committee

Human Resources / Personnel / Executive Officer

Library Staff Development Officer / Committee

$\square$ Senior Library Administrator

Librarian Designate

Does not have anyone responsible

Don't know

Other (please specify)

Does your library offer any diversity / equity programs or training for librarians? Please check all that are applicable.

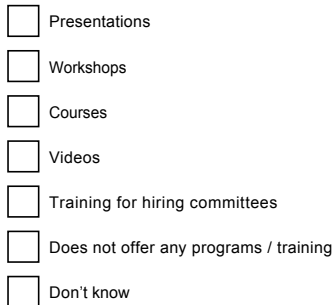

Other (please specify) 


\section{CANADIAN ACADEMIC LIBRARIANS DIVERSITY SURVEY}

Has your library ever conducted a diversity climate assessment to determine staff attitudes toward diversity?

Yes

No

Don't know

Other (please specify)

What steps does your library take to reach out and encourage applications from ABORIGINAL librarians? Please check all that are applicable.

Advertises in publications / on websites that target these librarians

$\square$ Advertises on listservs / discussion lists that target these librarians

Provides post-MLS internships / residencies / fellowships

$\square$ Liaises with library associations

Liaises with library schools

Provides financial support including scholarships

Does not take any steps

Don't know

Other (please specify)

Does your library have difficulty recruiting ABORIGINAL librarians?

Yes

No

Don't know

Other (please specify) 


\section{CANADIAN ACADEMIC LIBRARIANS DIVERSITY SURVEY}

What do you think are the biggest obstacles your library faces with respect to the recruitment of ABORIGINAL librarians? Please check all that are applicable.

$\square$ Limited pool of qualified applicants

Geographical location of institution

Failure on the part of hiring committees to follow Employment Equity / Affirmative Action Plan

Staff attitudes

Hiring freezes

Applicants choose not to self-identify / difficult to obtain information from applicants regarding racial / ethnic identity

Don't know

Other (please specify)

Do you feel that your library should be doing more to reach out and encourage applications from ABORIGINAL librarians?
Yes
No
Don't know

Other (please specify)

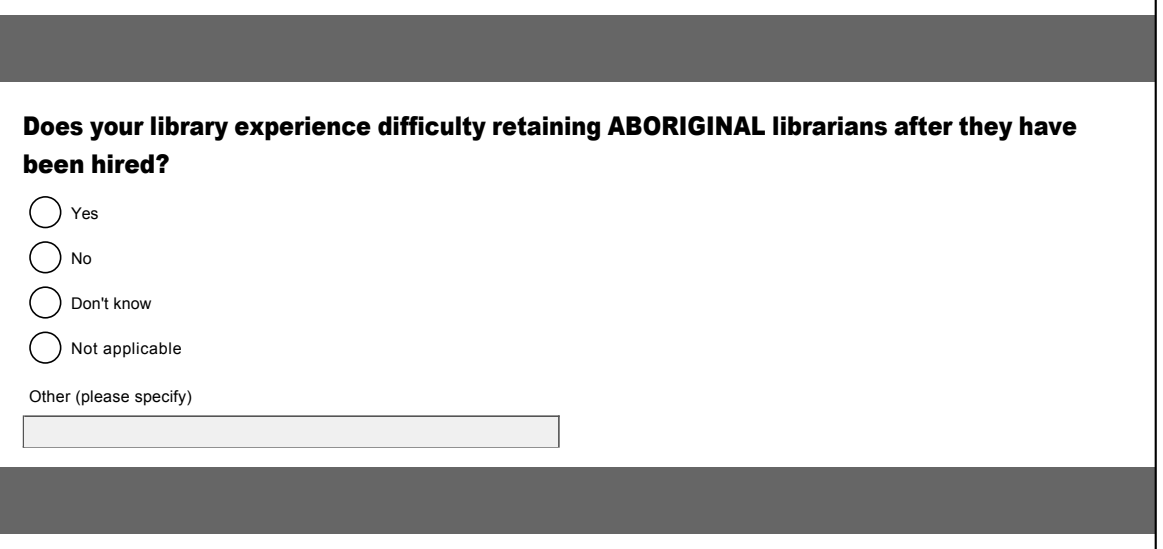




\section{CANADIAN ACADEMIC LIBRARIANS DIVERSITY SURVEY}

Why does your library experience difficulty retaining ABORIGINAL librarians? Please check all that are applicable.
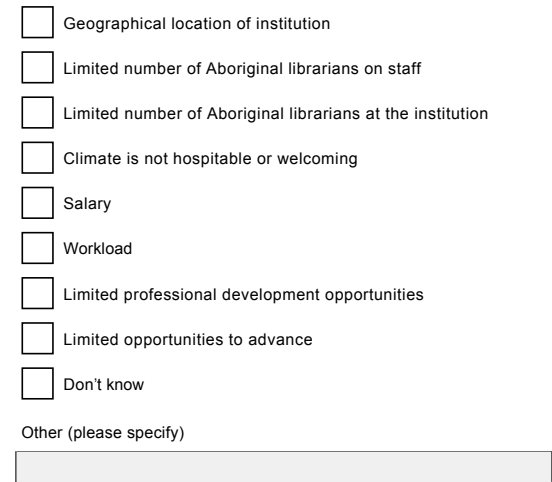

Do you consider your library to be a hospitable and welcoming place for ABORIGINAL librarians?

Yes

No

$\bigcirc$ Don't know

Not applicable

Other (please specify) 


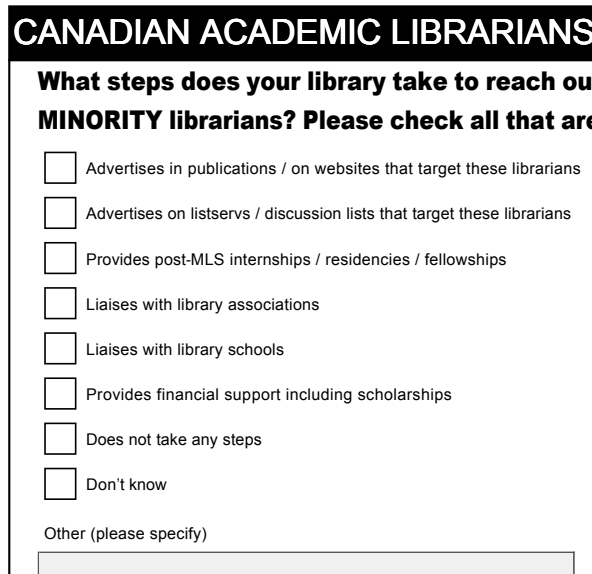

Does your library have difficulty recruiting VISIBLE MINORITY librarians?

Yes

No

Don't know

Other (please specify) 


\section{CANADIAN ACADEMIC LIBRARIANS DIVERSITY SURVEY}

What do you think are the biggest obstacles your library faces with respect to the recruitment of VISIBLE MINORITY librarians? Please check all that are applicable.

Limited pool of qualified applicants

Geographical location of institution

Failure on the part of hiring committees to follow Employment Equity / Affirmative Action Plan

Staff attitudes

Hiring freezes

$\square$ Applicants choose not to self-identify / difficult to obtain information from applicants regarding racial / ethnic identity

Don't know

Other (please specify)

Do you feel that your library should be doing more to reach out and encourage applications from VISIBLE MINORITY librarians?

Yes

$\bigcirc$ No

Don't know

Other (please specify)

Does your library experience difficulty retaining VISIBLE MINORITY librarians after they have been hired?

Yes

No

Don't know

Not applicable

Other (please specify) 


\section{CANADIAN ACADEMIC LIBRARIANS DIVERSITY SURVEY}

Why does your library experience difficulty retaining VISIBLE MINORITY librarians? Please check all that are applicable.
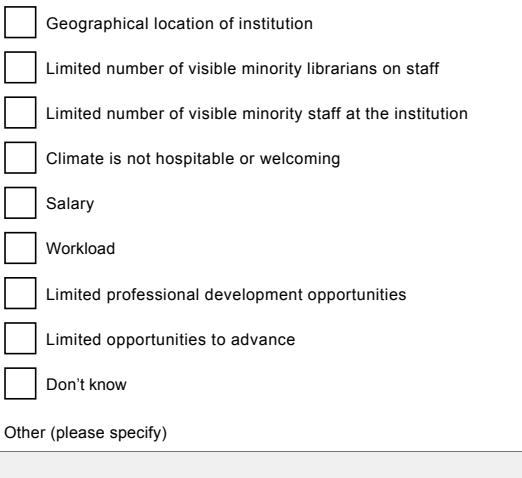

Do you consider your library to be a hospitable and welcoming place for VISIBLE MINORITY librarians?
Yes
No
Don't know
Not applicable
Other (please specify) of Aboriginal or visible minority librarians at your institution or in general? 


\section{CANADIAN ACADEMIC LIBRARIANS DIVERSITY SURVEY}

Statistics Canada Classification of Population Groups

Aboriginal peoples: First Nations (North American Indian), Métis or Inuit

Visible minorities: Chinese, South Asian, Black, Filipino, Latin American, South East Asian, Arab, West Asian, Korean or Japanese (Note: Population groups used by Statistics Canada on questionnaires that collect data on the visible minority population for Employment Equity purposes. The Employment Equity Act defines visible minorities as "persons, other than Aboriginal peoples, who are non-Caucasian in race or non-white in colour."

http://www.statcan.gc.ca/concepts/definitions/ethnicity-ethnicite-eng.htm)

* Are you a member of one of the equity-seeking groups above? Please specify which group you are a member of.

Aboriginal peoples (identify as Aboriginal)

Visible minorities (identify as visible minority)

Do not belong to either group (DO NOT identify as Aboriginal or visible minority)

Thank you for completing this survey!

Were you made aware of an Employment Equity / Affirmative Action policy when you applied for your present position?
$\bigcirc$ Yes
$\bigcirc$ No
Don't remember
Not applicable

Other (please specify) 


\section{CANADIAN ACADEMIC LIBRARIANS DIVERSITY SURVEY}

How were you made aware of it? Please check all that are applicable.

$\square$ I was sent information about the policy / a self-identification form after submitting my application

$\square$ I was told about the policy / invited to self-identify during the interview process by the hiring committee

$\square$ I was told about the policy / invited to self-identify during the interview process by the University Librarian / Director of Libraries / Dean of Libraries

$\square$ I don't remember

Other (please specify)

Did you self-identify as Aboriginal?

Yes

$\bigcirc$ No

Other (please specify)

Why did you not self-identify? Please check all that are applicable.

$\square$ I did not think it was important

$\square$ I did not think it would make a difference

$\square$ I wanted to be hired on my own merit

I was uncomfortable / afraid

Other (please specify) 


\section{CANADIAN ACADEMIC LIBRARIANS DIVERSITY SURVEY}

Have you participated in any of the following programs at your library / institution?
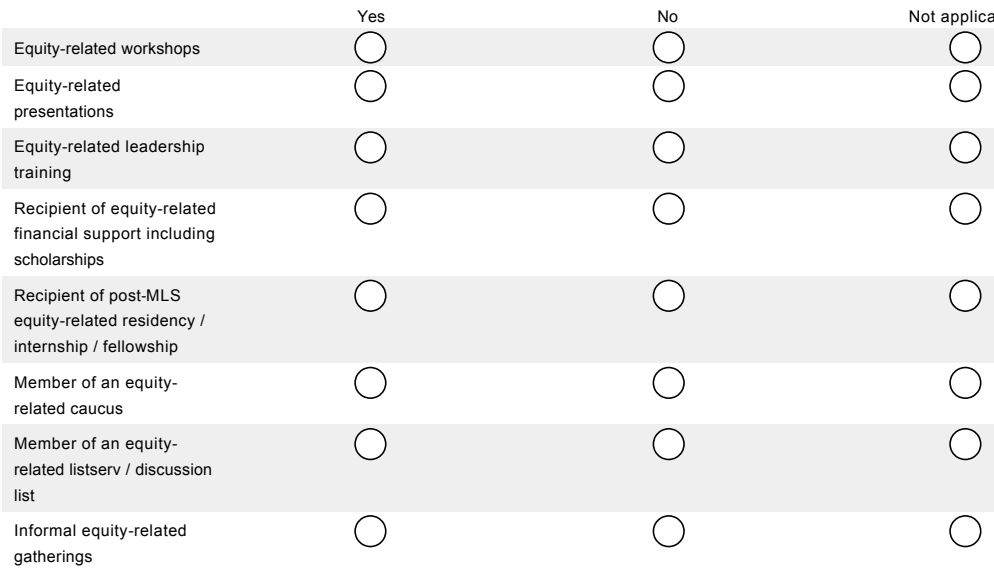

(

$\bigcirc$

0

financial support including

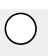

$\bigcirc$

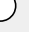

Member of an equity-

related caucus

$\bigcirc$

$\bigcirc$

O

O

gatherings

Other (please specify)

Is there anything that you would like to share regarding these programs?

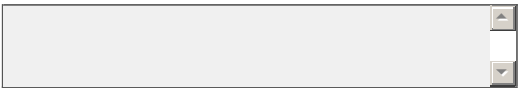

Are there any equity-related programs you would like to see offered by your library I institution? 


\section{CANADIAN ACADEMIC LIBRARIANS DIVERSITY SURVEY}

Were you / are you being mentored?

$\bigcirc$ Yes

No

Not applicable

Other (please specify)

What type of mentoring was / is this?

Formal library / institutional program

Informal mentoring relationship

Other (please specify)

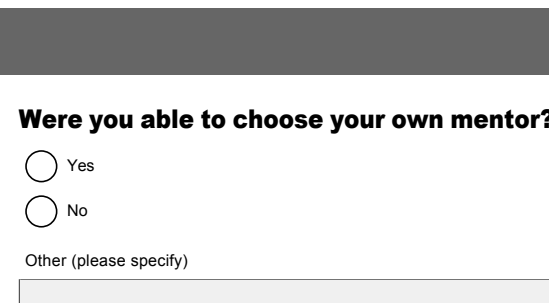

Was / is your mentor one of the following? Please check all that are applicable.

$\square$ Same gender

Aboriginal

Member of a visible minority

$\square$ Peer (same age / status)

$\square$ Senior colleague

$\square$ Department Head / Administrator

Other (please specify) 


\section{CANADIAN ACADEMIC LIBRARIANS DIVERSITY SURVEY}

Please rank your mentoring experience in the following areas.

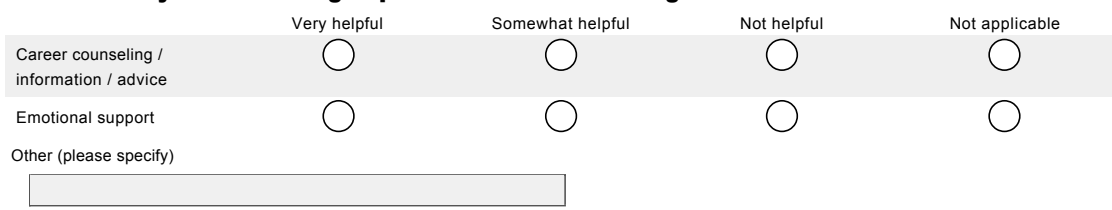

Is there anything you would like to share regarding your mentoring experience? 


\section{CANADIAN ACADEMIC LIBRARIANS DIVERSITY SURVEY}

Do you feel that you have been disadvantaged as an Aboriginal librarian with respect to any of the following?

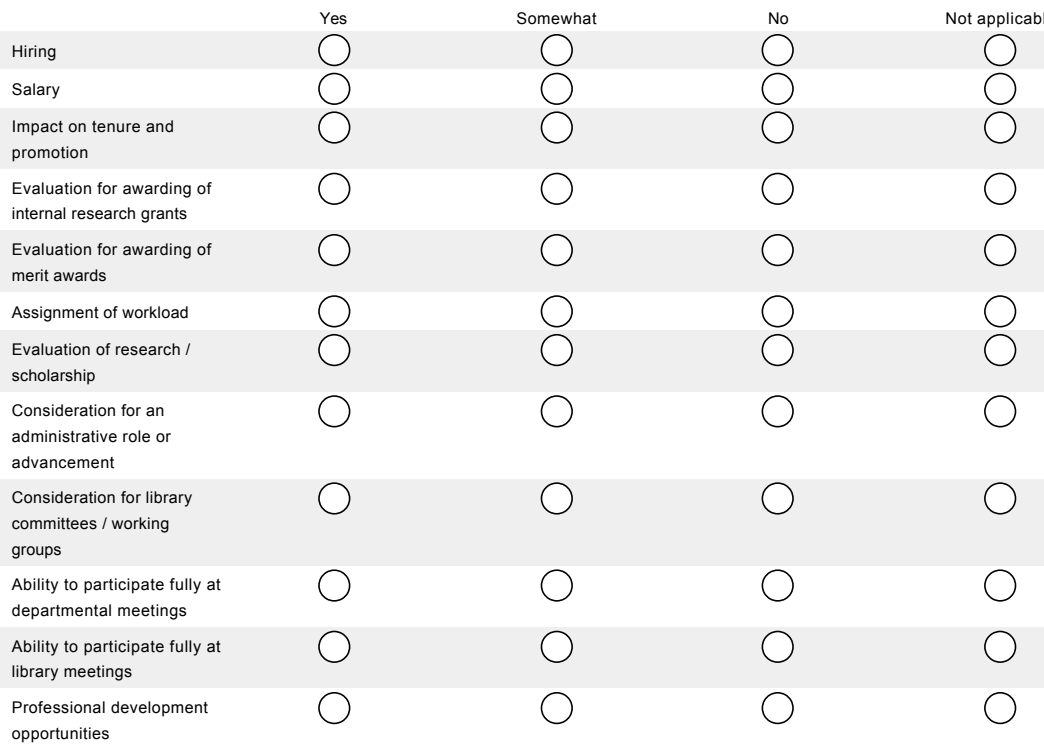

Other (please specify) 


\section{CANADIAN ACADEMIC LIBRARIANS DIVERSITY SURVEY}

Which best describes your experience with respect to the following statements?

I am treated with respect

and accepted as an equal

member by colleagues in

my department

My knowledge and work

contributions are valued by

colleagues in my

department

Colleagues in my

department welcome

difference and value

diversity

I feel free to speak my mind

and express my views

openly amongst colleagues

in my department

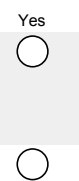

Somewhat

$\bigcirc$

No

$\bigcirc$

0

0

0

0

0
Not applicable

0

0

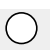

0

\section{(n)}

Which best describes your experience with respect to the following statements?

I am treated with respect

and accepted as an equal

member by colleagues in

the library outside my

department

My knowledge and work

contributions are valued by

colleagues in the library

outside my department

Colleagues in the library

outside my department

welcome difference and

value diversity

I feel free to speak my mind

and express my views

openly amongst colleagues

in the library outside my

department

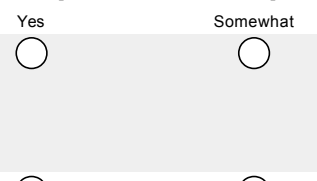

No

$\bigcirc$

Not applicable

$\bigcirc$

O

$\bigcirc$

0

0

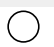




\section{CANADIAN ACADEMIC LIBRARIANS DIVERSITY SURVEY}

Is there anything you would like to share regarding your experience as an Aboriginal librarian in your department and/or library?

Do you feel the climate with respect to diversity has improved in your DEPARTMENT since you were hired?
Yes
Somewhat
$\bigcirc$ No

Other (please specify)

Do you feel the climate with respect to diversity has improved in your LIBRARY since you were hired?
$\bigcirc$ res
Somewhat
$\bigcirc$ No

Other (please specify) 


\section{CANADIAN ACADEMIC LIBRARIANS DIVERSITY SURVEY}

What steps can your library take to improve the climate with respect to diversity? Please check all that are applicable.

$\square$ Provide staff diversity training and development

Provide social / cultural programs to increase awareness of diversity

$\square$ Management / administration should provide leadership with respect to diversity issues

Conduct a diversity climate assessment

Hire more diverse staff

Other (please specify)

How can your library better support you as an Aboriginal librarian?

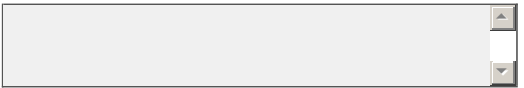

Are you a current or past member of a library association in Canada? Please check all that are applicable.

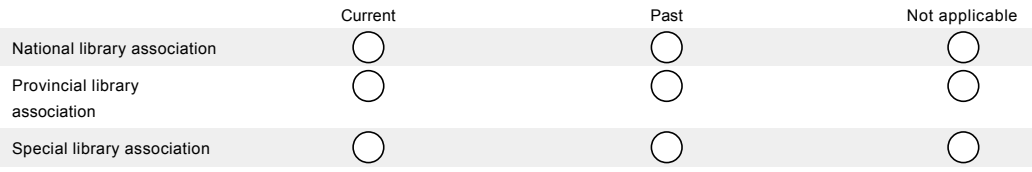

Other (please specify) 


\section{CANADIAN ACADEMIC LIBRARIANS DIVERSITY SURVEY}

Which best describes your experience when participating in the following library association activities in Canada? Please check all that are applicable.

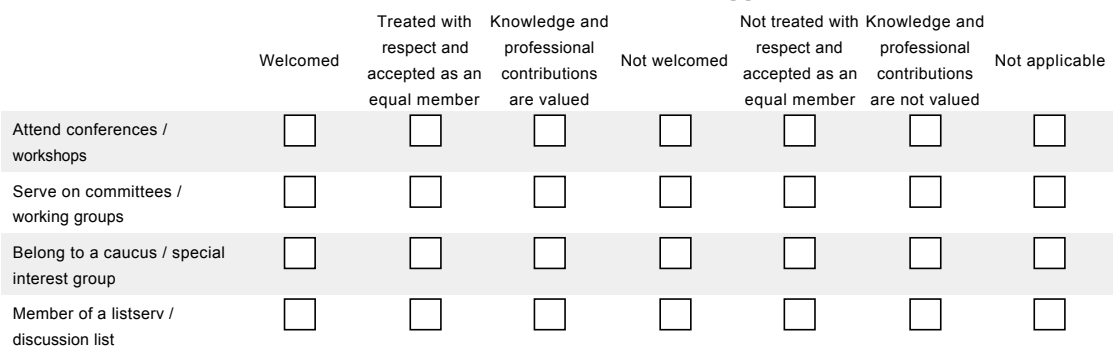

Other (please specify)

Is there anything you would like to share regarding your experience as an Aboriginal librarian participating in library association activities in Canada? 


\section{CANADIAN ACADEMIC LIBRARIANS DIVERSITY SURVEY}

Have you participated in any of the following programs for Aboriginal librarians sponsored by a library association or another organization in or outside Canada?

Attend equity-related

conferences / workshops in

Canada

Attend equity-related

conferences / workshops

outside Canada

Serve on equity-related

committees / working

groups in Canada

Serve on equity-related

committees / working

groups outside Canada

Member of an equity-

related caucus in Canada

Member of an equity-

related caucus outside

Canada

Member of an equity-

related listserv / discussion

list in Canada

Member of an equity-

related listserv / discussion

list outside Canada

Other (please specify)
Yes

No

$\bigcirc$

$\bigcirc$

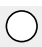

0

0

0

0

0

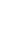

Not applicable

0

0

0

0

0

0

0

0

Is there anything you would like to share regarding these programs? 


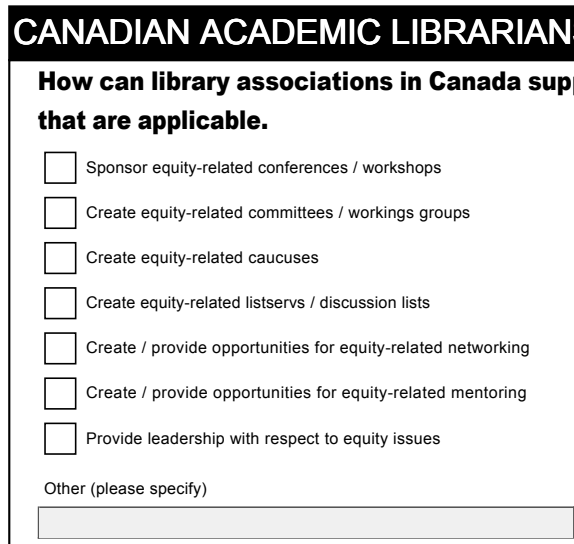

Is there anything else that you would like to share with respect to your experience as an Aboriginal librarian employed in a Canadian academic library and/or your experience as an Aboriginal librarian relating to library associations in Canada?

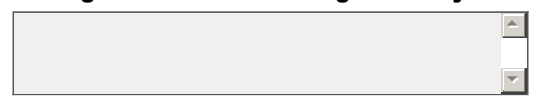

Thank you for completing this survey! 


\section{CANADIAN ACADEMIC LIBRARIANS DIVERSITY SURVEY}

Please specify your race / ethnic identity.

Chinese

South Asian (East Indian, Pakistani, Sri Lankan, etc.)

Black

Filipino

Latin American

Southeast Asian (Cambodian, Malaysian, Laotian, Vietnamese)

Arab

West Asian (Afghanian, Iranian, etc.)

Japanese

Korean

Multiple visible minorities

Other (please specify)

Were you made aware of an Employment Equity / Affirmative Action policy when you applied for your present position?

Yes

No

Don't remember

Not applicable

Other (please specify) 


\section{CANADIAN ACADEMIC LIBRARIANS DIVERSITY SURVEY}

How were you made aware of it? Please check all that are applicable.

$\square$ I was sent information about the policy / a self-identification form after submitting my application

$\square$ I was told about the policy / invited to self-identify during the interview process by the hiring committee

$\square$ I was told about the policy / invited to self-identify during the interview process by the University Librarian / Director of Libraries / Dean of Libraries

$\square$ I don't remember

Other (please specify)

Did you self-identify as a member of a visible minority?

$\bigcirc$ Yes

$\bigcirc$ No

Other (please specify)

Why did you not self-identify? Please check all that are applicable.

$\square$ I did not think it was important

I did not think it would make a difference

$\square$ I wanted to be hired on my own merit

I was uncomfortable / afraid

Other (please specify) 


\section{CANADIAN ACADEMIC LIBRARIANS DIVERSITY SURVEY}

Have you participated in any of the following programs at your library / institution?
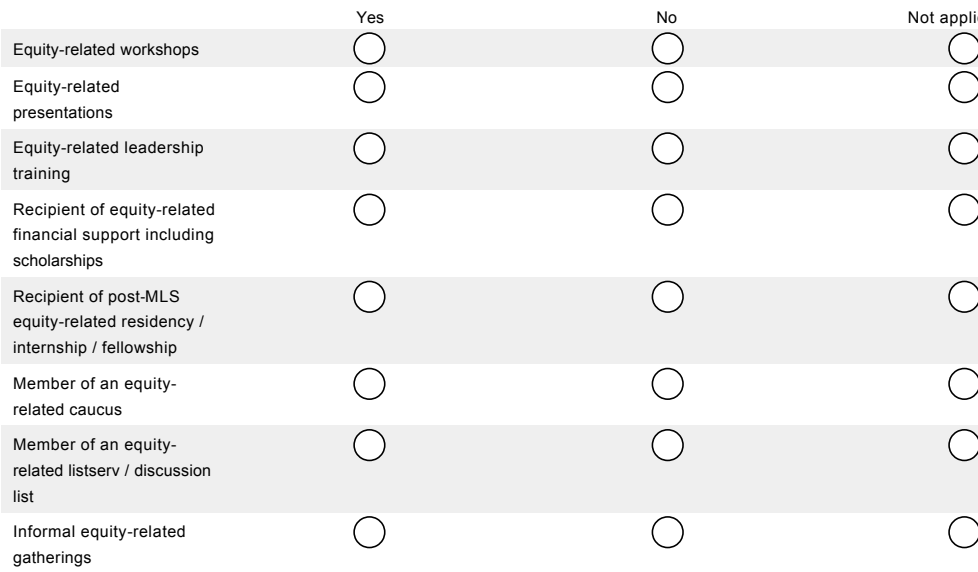

0

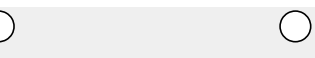

O

$\bigcirc$

O

O

O

(

$\bigcirc$

gatherings

Other (please specify)

Is there anything you would like to share regarding these programs?

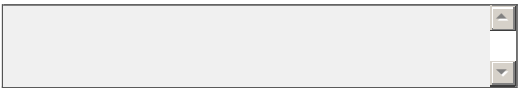

Are there any equity-related programs you would like to see offered by your library I institution? 


\section{CANADIAN ACADEMIC LIBRARIANS DIVERSITY SURVEY}

Were you / are you being mentored?

$\bigcirc$ Yes

No

Not applicable

Other (please specify)

What type of mentoring was / is this?

Formal library / institutional program

Informal mentoring relationship

Other (please specify)

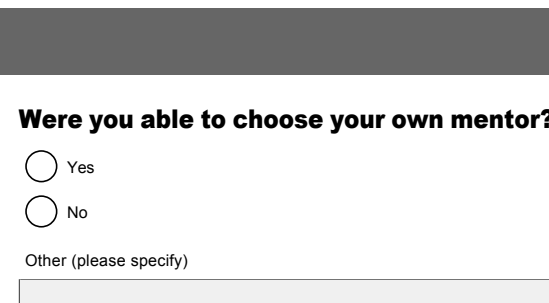

Was / is your mentor one of the following? Please check all that are applicable.
$\square$ Same gender
Aboriginal
$\square$ Member of a visible minority
$\square$ Peer (same age / status)
$\square$ Senior colleague
$\square$ Department Head / Administrator
Other (please specify) 


\section{CANADIAN ACADEMIC LIBRARIANS DIVERSITY SURVEY}

Please rank your mentoring experience in the following areas.

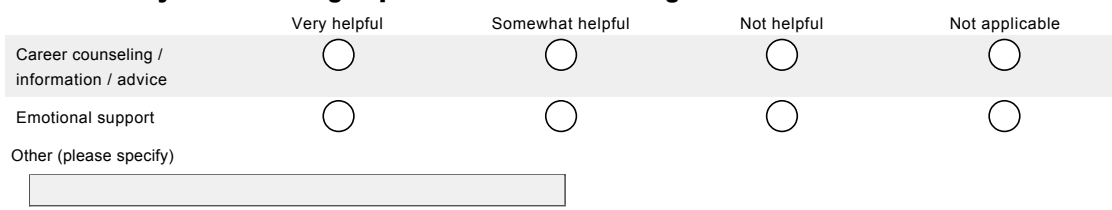

Is there anything you would like to share regarding your mentoring experience? 


\section{CANADIAN ACADEMIC LIBRARIANS DIVERSITY SURVEY}

Do you feel that you have been disadvantaged as a visible minority librarian with respect to any of the following?

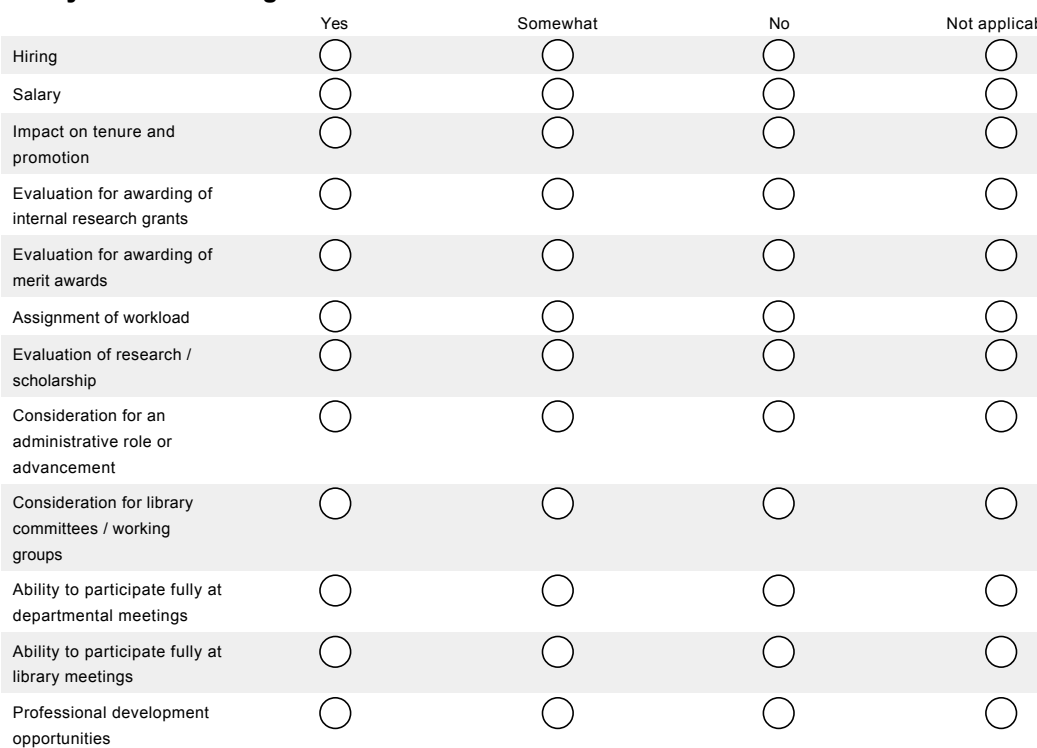

Other (please specify) 


\section{CANADIAN ACADEMIC LIBRARIANS DIVERSITY SURVEY}

Which best describes your experience with respect to the following statements?

I am treated with respect

and accepted as an equal

member by colleagues in

my department

My knowledge and work

contributions are valued by

colleagues in my

department

Colleagues in my

department welcome

difference and value

diversity

I feel free to speak my mind

and express my views

openly amongst colleagues

in my department

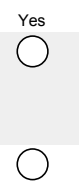

Somewhat

0

No

$\bigcirc$

0

0

0

0

0
Not applicable

0

0

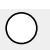

0

\section{(n)}

Which best describes your experience with respect to the following statements?

I am treated with respect

and accepted as an equal

member by colleagues in

the library outside my

department

My knowledge and work

contributions are valued by

colleagues in the library

outside my department

Colleagues in the library

outside my department

welcome difference and

value diversity

I feel free to speak my mind

and express my views

openly amongst colleagues

in the library outside my

department

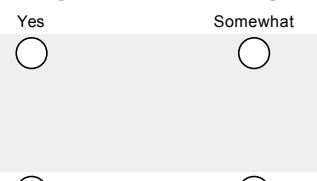

No

$\bigcirc$

Not applicable

$\bigcirc$

O

$\bigcirc$

0

0

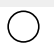




\section{CANADIAN ACADEMIC LIBRARIANS DIVERSITY SURVEY}

Is there anything you would like to share regarding your experience as a visible minority librarian in your department and/or library?

Do you feel the climate with respect to diversity has improved in your DEPARTMENT since you were hired?

Yes
Somewhat
No

Other (please specify)

Do you feel the climate with respect to diversity has improved in your LIBRARY since you were hired?

Yes

Somewhat

$\bigcirc$ No

Other (please specify) 


\section{CANADIAN ACADEMIC LIBRARIANS DIVERSITY SURVEY}

What steps can your library take to improve the climate with respect to diversity? Please check all that are applicable.

$\square$ Provide diversity staff training and development

$\square$ Provide social / cultural programs to increase awareness of diversity

Management / administration should provide leadership with respect to diversity issues

Conduct a diversity climate assessment

Hire more diverse staff

Other (please specify)

How can your library better support you as a visible minority librarian?

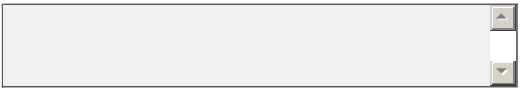

Are you a current or past member of a library association in Canada? Please check all that are applicable.

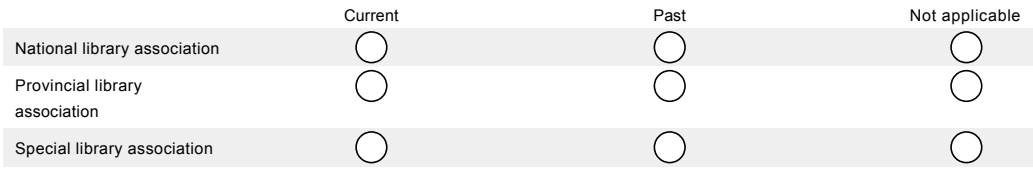

Other (please specify) 


\section{CANADIAN ACADEMIC LIBRARIANS DIVERSITY SURVEY}

Which best describes your experience when participating in the following library association activities in Canada? Please check all that are applicable.

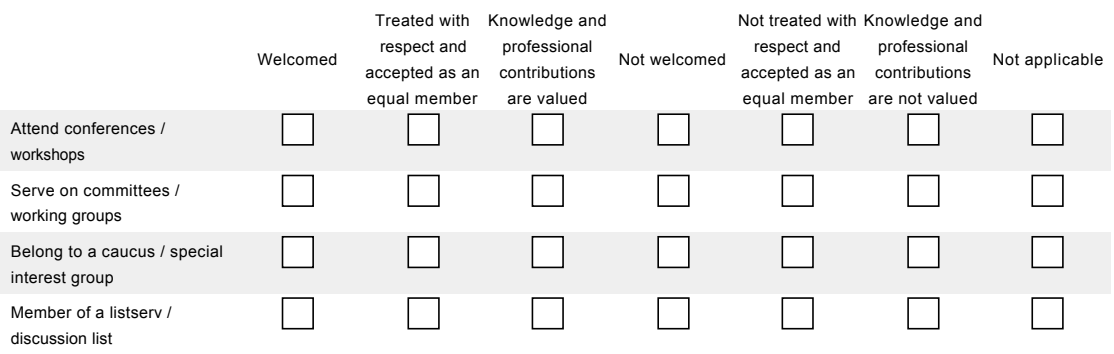

Other (please specify)

Is there anything you would like to share regarding your experience as a visible minority librarian participating in library association activities in Canada? 


\section{CANADIAN ACADEMIC LIBRARIANS DIVERSITY SURVEY}

Have you participated in any of the following programs for visible minority librarians sponsored by a library association or another organization in or outside Canada?

Attend equity-related

conferences / workshops in

Canada

Attend equity-related

conferences / workshops

outside Canada

Serve on equity-related

committees / working

groups in Canada

Serve on equity-related

committees / working

groups outside Canada

Member of an equity-

related caucus in Canada

Member of an equity-

related caucus outside

Canada

Member of an equity-

related listserv / discussion

list in Canada

Member of an equity-

related listserv / discussion

list outside Canada

Other (please specify)
Yes

$\bigcirc$

0

0

0

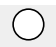

0

0

0
No

0

0

0

0

0

0

0

0

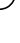

Not applicable

0

0

0

0

0

0

0

$\bigcirc$

Is there anything you would like to share regarding these programs? 


\section{CANADIAN ACADEMIC LIBRARIANS DIVERSITY SURVEY}

How can library associations in Canada support visible minority librarians? Please check all that are applicable.

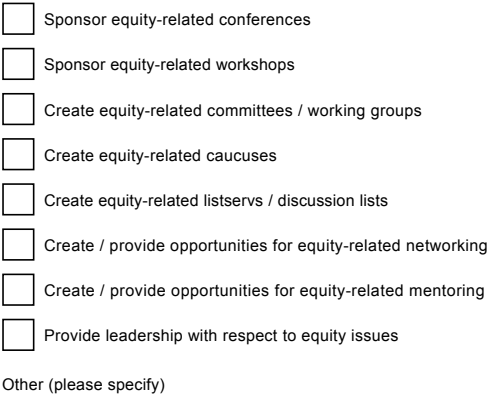

Is there anything else that you would like to share with respect to your experience as a visible minority librarian employed in a Canadian academic library and/or your experience as a visible minority librarian relating to library associations in Canada?

Thank you for completing this survey! 


\section{Notes}

1. Department of Justice, "Employment Equity Act," available online at http://laws-lois. justice.gc.ca/eng/acts/E-5.401/page-1.html [accessed 4 June 2012].

2. Kaetrena D. Davis-Kendrick, The Kaleidoscope Concern: An Annotated Chronological Bibliography of Diversity, Recruitment, Retention, and Other Concerns Regarding African American and Ethnic Library Professionals in the United States (Chicago: Association of College and Research Libraries, 2009), available online at www.ala.org/acrl/sites/ala.org.acrl/files/content/publications/booksanddigitalresources/digital/kaleidoscopic.pdf [accessed 19 March 2012].

3. K.-S. Kim and S.-C. J Sin, "Increasing Ethnic Diversity in LIS: Strategies Suggested by Librarians of Color," Library Quarterly 78, no. 2 (2008): 157.

4. Ibid., 153 .

5. Ibid., 168.

6. Ibid., 169.

7. Ibid., 171.

8. Ione T. Domasco and Dracine Hodges, "Tenure and Promotion Experiences of Academic Librarians of Color," College \& Research Libraries 73, no. 3 (May 2012): 279, available online at

http://crl.acrl.org/content/73/3/279.full.pdf+html [accessed 24 August 2012].

9. Ibid., 299.

10. Ibid., 300.

11. Association of College \& Research Libraries, Diversity Standards: Cultural Competency for Academic Libraries (2012), 1, available online at www.ala.org/acrl/standards/diversity [accessed 24 October 2012].

12. Teresa Y. Neely and Lorna Peterson. Achieving Racial and Ethnic Diversity among Academic and Research Librarians: The Recruitment, Retention, and Advancement of Librarians of Color: A White Paper by the ACRL Board of Directors (July 2007), 5, available online at www.ala.org/acrl/files/ publications/.../ACRL_AchievingRacial.pdf [accessed 24 June 2012].

13. Charlene Maxey Harris and Toni Anaya, Diversity Plans and Programs, SPEC Kit 319 (Washington: Association of Research Libraries, 2010), 11, available online at www.arl.org/bm $\sim \mathrm{doc} /$ spec-319-web.pdf [accessed 26 November 2012].

14. The 8Rs Research Team, The Future of Human Resources in Canadian Libraries (Edmonton: University of Alberta, 2005), 44, available online at www.ls.ualberta.ca/8rs/8RsFutureofHRLibraries. pdf [accessed 30 January 2012].

15. Deborah Lee, "Indigenous Knowledges and the University Library," Canadian Journal of Native Education 31, no. 1 (2008): 3, available online at http://ecommons.usask.ca/bitstream/ handle/10388/293/Lee_Indigenous\%20Knowledges\%20manuscript.pdf?sequence=1 [accessed 30 January 2012].

16. Multitype Library Board, Creating a Representative Library Workforce in Saskatchewan, available online at www.lib.sk.ca/MLB-Documents-Representative-Library-Workforce [accessed 30 January 2012].

17. Maha Kumaran, Leadership in Libraries: A Focus on Ethnic-Minority Librarians (Oxford: Chandos, 2012), xvi.

18. Statistics Canada, "Aboriginal Peoples," available online at http://www12.statcan.ca/ census-recensement/2006/rt-td/ap-pa-eng.cfm [accessed 30 January 2012].

19. Statistics Canada, "Aboriginal Peoples in Canada in 2006: Inuit, Métis, and First Nations, 2006 Census," available online at http://www12.statcan.ca/census-recensement/2006/as-sa/97-558/ pdf/97-558-XIE2006001.pdf [accessed 30 January 2012].

20. In 2007, the UN Committee on the Elimination of Racial Discrimination expressed concerns over the Canadian government's use of the term "visible minorities," with country Rapporteur Mr. Thornberry expressing concern that "the use of the term visible minorities seemed to somehow indicate somehow that 'whiteness' was the standard, all others differing from that being visible," Committee on Elimination of Racial Discrimination Considers Report of Canada, available online at www.ohchr.org/en/NewsEvents/Pages/DisplayNews.aspx?NewsID=8250\&LangID=E [accessed 20 October 2012]. Canada meanwhile has argued that the term "visible minority" is "specific to the administration of the Employment Equity Act that seeks to address conditions or disadvantage in employment, in areas of federal jurisdiction, experienced by four specified groups-Aboriginal peoples, persons with disabilities, members of visible minorities, and women." International Convention on the Elimination of All Forms of Racial Discrimination: Nineteenth and Twentieth Reports of Canada, 12, available online at www.pch.gc.ca/ddp-hrd/docs/cerd/rpprts_19_20/19-20-eng.pdf [accessed 20 October 2012].

21. Citizenship and Immigration Canada, "Evaluation of the Welcoming Communities Initiatives," available online at www.cic.gc.ca/english/resources/evaluation/wci/section4.asp [accessed 
20 March 2012].

22. Citizenship and Immigration Canada, "Annual Report on the Operation of the Canadian Multiculturalism Act 2007-2008," available online at www.cic.gc.ca/English/resources/publications/multi-report2008/part1.asp [accessed 20 March 2012].

23. CAUT Almanac of Post-Secondary Education 2011-2012, 20, available online at www.caut. ca/uploads/2011_2_Staff.pdf [accessed 20 February 2012].

24. "York University Vital Statistics 101," available online at www.yorku.ca/gro/York\%20101.ppt [accessed 20 February 2012].

25. Statistics Canada, "National Occupational Classification for Statistics (720 - F011) - Special Interest Profiles," available online at http://www12.statcan.gc.ca/census-recensement/2006/dp-pd/ prof/sip/Rp-eng.cfm?LANG=E\&APATH $=3 \& D E T A I L=0 \& D I M=0 \& F L=A \& F R E E=0 \& G C=0 \& G I D=0$ $\& G K=0 \& G R P=1 \& P I D=97611 \& P R I D=0 \& P T Y P E=97154 \& S=0 \& S H O W A L L=0 \& S U B=0 \&$ Temporal $=2$ $006 \&$ THEME $=74 \& V I D=0 \& V N A M E E=\& V N A M E F=$ [accessed 13 February 2012].

26. "Free occupation data is only available at 3 digit level. Anything beyond that would be a custom data cost a fee starting at \$1100," e-mail from Urfan Sayed, Statistics Canada, February $13,2012$.

27. Lee, “Indigenous Knowledges," 1.

28. Statistics Canada, "Labour Force Activity (8), Aboriginal Identity (8B), Age Groups (13A), Sex (3) and Area of Residence (6A) for the Population 15 Years and Over of Canada, Provinces and Territories, 2001 and 2006 Censuses - 20\% Sample Data," available online at http://www12. statcan.ca/census-recensement/2006/dp-pd/tbt/Rp-eng.cfm?LANG=E\&APATH=3\&DETAIL=0\&D $\mathrm{IM}=0 \& \mathrm{FL}=\mathrm{A} \& \mathrm{FREE}=0 \& \mathrm{GC}=0 \& \mathrm{GID}=0 \& \mathrm{GK}=0 \& \mathrm{GRP}=1 \& \mathrm{PID}=92101 \& \mathrm{PRID}=0 \& \mathrm{PTYPE}=88971,9715$ $4 \& S=0 \& S H O W A L L=0 \& S U B=0 \&$ Temporal $=2006 \&$ THEME $=73 \& V I D=0 \&$ VNAMEE $=\&$ VNAMEF $=$ [accessed 13 February 2012].

29. "Data on this is self-reported by students only, and we don't report it to ALISE; this would be the same for other Canadian schools, where it's typically illegal to collect that information without consent. We only report international/domestic numbers. So I guess the answer is 'no,' there's nothing that would help the requester." E-mail from Susan Brown, Assistant Dean, Administration, Faculty of Information, U of T, June 23, 2011. And, "ALISE does not gather student ethnic or racial diversity data from Canadian institutions. My understanding is that Canadian universities are not allowed by law to gather or disseminate such information even in the aggregate." E-mail from Danny Wallace, ALISE Statistical Report Manager, July 6, 2011.

30. The Program requires organizations that have 100 or more employees who want to bid on a federal government contract or standing offer of $\$ 200,000$ to sign a Certificate of Commitment to implement employment equity. They are also subject to compliance reviews that "assess the organization's employment equity program to ensure that it fulfills the terms of the Certificate of Commitment by meeting the Requirements of the Federal Contractors Program, which are based on the Employment Equity Act." See www.hrsdc.gc.ca/eng/labour/equality/fcp/index.shtml and

www.hrsdc.gc.ca/eng/labour/equality/fcp/reviews/index.shtml [accessed 29 January 2012].

31. The Equity Office, Queen's University, "2011 Academic Positions-Employment Equity Report by Rank," available online at www.queensu.ca/equity/content.php?page=Faculty [accessed 14 April 2012].

32. University of Toronto, "Employment Equity Report," 5, available online at www.hrandequity.utoronto.ca/Assets/HR+Digital+Assets/Equity+Officers+Annual+Reports/2011eer.pdf [accessed 14 April 2012].

33. Human Resources, University of Lethbridge, "Best Practices for Hiring with a Focus on Equity and Diversity," available online at www.uleth.ca/diversityadvantage/documents/FacultyEquityHiringGuideOct07final_web.pdf [accessed 16 May 2012].

34. York University Faculty Association, "Example Affirmative Action Plans for Hiring," available online at www.yufa.org/contract/aa_examples.html [accessed 16 May 2012].

35. Memorial University, "Employment Equity," available online at www.mun.ca/policy/site/ policy.php?id=124 [accessed 16 May 2012].

36. Canadian Association of University Teachers, "Policy Statement on Equity," available online at www.caut.ca/pages.asp?page=268\&lang=1 [accessed 16 May 2012].

37. Queen's University Faculty Association, 2011-2015 Collective Agreement, available online at www.qufa.ca/ca/ [accessed 16 May 2012].

38. ClimateQUAL, "Partners," available online at www.climatequal.org/about/partners [accessed 4 June 2012].

39. Multitype Library Board, Creating a Representative Library Workforce, 2.

40. Kumaran, Leadership in Libraries, 6.

41. Edith Maureen Fisher, "Modern Racism and Academic Librarianship in a Period of Diversity," Academic Libraries: Achieving Excellence in Higher Education (Chicago: Association of College and Research Libraries, 1992), 73. 
42. American Federation of Teachers, "Promoting Racial and Ethnic Diversity in the Faculty: What Higher Education Unions Can Do," 12, available online at www.aft.org/pdfs/highered/facultydiversity0310.pdf [accessed 16 May 2012].

43. The Employment Equity Act came into effect in 1986.

44. Statistics Canada, "Classification of Visible Minority," available online at www.statcan. gc.ca/concepts/definitions/minority01-minorite01a-eng.htm [accessed 21 May 2011].

45. The 8Rs Research Team, The Future of Human Resources, 44.

46. Domasco and Hodges, "Tenure and Promotion Experiences," 292.

47. Ibid, 296.

48. Karen Downing, "The Relationship between Social Identity and Role Performance among Academic Librarians," (PhD diss., University of Michigan, 2009), 188, 206, available online at http://deepblue.lib.umich.edu/bitstream/2027.42/62396/1/kdown_1.pdf [accessed 24 June 2012].

49. Domasco and Hodges, "Tenure and Promotion Experiences," 296.

50. Neely and Peterson, Achieving Racial and Ethnic Diversity, 6.

51. Association of College \& Research Libraries, Diversity Standards, 1.

52. Human Resources and Skills Development Canada, "Federal Contractors Program - Requirements," available online at www.hrsdc.gc.ca/eng/labour/equality/fcp/requirements/page01. shtml [accessed 6 October 2012].

53. The 8Rs Research Team, The Future of Human Resources, 45.

54. York University full-time librarians by equity status in 2012: visible minority - 21\%, Aboriginal $-2 \%$ (data not verified).

55. Ashley E. Bonnette, “Mentoring Minority Librarians up the Career Ladder," Library Administration and Management 18, no. 3 (2004): 138.

56. Linda Musser, "Effective Retention Strategies for Diverse Employees," Journal of Library Administration 33, no. 1/2 (2001): 68.

57. Kim and Sin, "Increasing Ethnic Diversity," 157.

58. Ibid, 157.

59. Ibid, 161-62.

60. Statistics Canada, "Aboriginal Identity Population, by Province and Territory (2006 Census)," available online at www.statcan.gc.ca/tables-tableaux/sum-som/101/cst01/demo60a-eng. htm [accessed 24 October 2012].

61. Multitype Library Board, Creating a Representative Library Workforce, 4-5.

62. Lisa K. Hussey, "Why Librarianship? An Exploration of the Motivations of Ethnic Minorities to Choose Library and Information Science as a Career," Advances in Library Administration and Organization 28 (2009): 159.

63. "Visible Minority Librarians of Canada Network," available online at

www.cla.ca/AM/Template.cfm?Section=Networks1\&Template=/CM/HTMLDisplay. cfm\&ContentID=12227\&FuseFlag=1 [accessed 24 October 2012].

64. Tami Echavarria and Andrew B. Wertheimer, "Surveying the Role of Ethnic-American Library Associations," Library Trends 46, no.2 (Fall 1997): 389-90.

65. Kim and Sin, "Increasing Ethnic Diversity," 155.

66. Karen Downing, Camila A. Alire, and Jon E. Cawthorne, "Library Leadership Development: Institutional Commitment, Increasing Underrepresented Populations and Impacting the Information Profession," in Professional Development: Pathways to Leadership in the Library and Information World, eds. Ann Ritchie and Clare Walker (Munich: K.G. Saur Verlag, 2007), 36. 